\title{
DID COVID-19 CHANGE LIFE INSURANCE OFFERINGS?
}

\author{
Timothy F. Harris \\ Aaron Yelowitz \\ Charles J. Courtemanche \\ Working Paper 28172 \\ http://www.nber.org/papers/w28172
NATIONAL BUREAU OF ECONOMIC RESEARCH
1050 Massachusetts Avenue
Cambridge, MA 02138 \\ December 2020
}

We thank Compulife for generously providing life insurance pricing data. The views expressed herein are those of the authors and do not necessarily reflect the views of the National Bureau of Economic Research.

NBER working papers are circulated for discussion and comment purposes. They have not been peer-reviewed or been subject to the review by the NBER Board of Directors that accompanies official NBER publications.

(C) 2020 by Timothy F. Harris, Aaron Yelowitz, and Charles J. Courtemanche. All rights reserved. Short sections of text, not to exceed two paragraphs, may be quoted without explicit permission provided that full credit, including $(\odot$ notice, is given to the source. 
Did COVID-19 Change Life Insurance Offerings?

Timothy F. Harris, Aaron Yelowitz, and Charles J. Courtemanche

NBER Working Paper No. 28172

December 2020

JEL No. D81,I13

\section{$\underline{\text { ABSTRACT }}$}

The profitability of life insurance offerings is contingent on accurate projections and pricing of mortality risk. The COVID-19 pandemic created significant uncertainty, with dire mortality predictions from early forecasts resulting in widespread government intervention and greater individual precaution that reduced the projected death toll. We analyze how life insurance companies changed pricing and offerings in response to COVID-19 using monthly data on term life insurance policies from Compulife. We estimate event-study models that exploit wellestablished variation in the COVID-19 mortality rate based on age and underlying health status. Despite the increase in mortality risk and significant uncertainty, we find limited evidence that life insurance companies increased premiums or decreased policy offerings due to COVID-19.

Timothy F. Harris

Department of Economics

Illinois State University

College of Arts and Sciences

Stevenson Hall 425

Normal, IL 61790

tfharr1@ilstu.edu

Aaron Yelowitz

University of Kentucky

Department of Economics

335 Business and Economics Building

Lexington, KY 40506-0034

aaron@uky.edu
Charles J. Courtemanche

Department of Economics

Gatton College of Business and Economics

University of Kentucky

Lexington, KY 40506-0034

and NBER

courtemanche@uky.edu 


\section{Introduction}

Since the 2019 novel coronavirus (SARS-CoV-2) first emerged, there has been substantial uncertainty regarding the magnitude of the increase in mortality risk. In March 2020, a highly cited study from Imperial College (Ferguson et al., 2020) reported that uncontrolled spread of coronavirus in the U.S. could lead to 2.2 million fatalities, based on key assumptions such as 80 percent of the population ultimately getting COVID-19 and an infection fatality rate (IFR) of 0.9 percent. The modeling led to widespread action by policymakers in the U.S. and other countries to reduce transmission; within three days of the publication, California implemented the firstin-the-nation shelter-in-place order (Friedson et al., 2020), and most other states followed quickly thereafter.

As of November 2020, the COVID-19 death toll in the U.S. has been an order of magnitude below this projection. The difference between the most pessimistic forecasts and actual fatalities is likely due to changes in behavior-such as better handwashing, staying home more, and wearing facemasks or social distancing when outside the home - that are partly voluntary and partly induced by government suppression and mitigation policies (Courtemanche et al., 2020; Hsiang et al., 2020; Lyu and Wehby, 2020). While the average IFR has been the subject of debate in the literature due to different methods of accounting for undetected mild or asymptomatic infections, most studies put it in the range of 0.5 to 1 percentsimilar to the rate used by the Imperial College report, and an order of magnitude deadlier than the flu (Abbott and Douglas, 2020).

The duration and magnitude of increased mortality risk from COVID-19 are contingent on many uncertain events, such as the availability and efficacy of vaccines (Corum and Zimmer, 2020), the ability to implement technological innovations like pooled testing (Mandavilli, 2020), at-home testing, and contact tracing, and innovations in treating those who contract COVID-19 with therapeutics like Remdesivir (Beigel et al., 2020). In addition to these factors, health messaging has been conflated with political considerations, contributing to more uncertainty. 
Underlying uncertainty about the direct and indirect effects of the virus, policy missteps, incorrect forecasts, and uncertainty about longer-run consequences all provide challenges for the life insurance industry, which relies on accurate estimates of mortality risk. In this study, we use monthly data on approximately 800,000 policies from 95 distinct companies listed on Compulife, a key distributor of life insurance quotes, to analyze the influence of COVID-19 on both term life insurance pricing and policy offerings. One key prediction that comes from models like Ericson and Sydnor (2017) is that insurance premiums should respond to exogenous changes in overall risk, which is precisely what happened due to COVID-19. Such short-run changes are well documented for automobile insurance, where reductions in driving and accident claims led to premium refunds early during the pandemic (Scism, 2020).

To analyze the influence of increased mortality risk on life insurance premiums and offerings, we exploit well-known and widely-accepted variation in mortality risks from COVID-19 originating from age and comorbidities. ${ }^{1}$ Those with chronic conditions or advanced age are far more likely than others to be hospitalized or die from the virus (CDC, 2020). Early evidence from mainland China estimated IFR of 7.8 percent for those aged over 80 and over, 4.28 percent for those aged 70-79, and 1.93 percent for those aged 60-69, compared to 0.03 percent for young adults aged 20-29 (Verity et al., 2020). As a consequence, the direct health consequences of the virus (such as through mortality) and indirect effects (such as through foregone preventative care, mental health consequences, or rising obesity) are far more pronounced for older, less-healthy individuals than for younger, healthier individuals, especially for mortality in the short-run. ${ }^{2}$

This variation in mortality risk allows for the construction of treatment and control groups that we analyze using event-study models. Specifically, we estimate hedonic

\footnotetext{
${ }^{1}$ There also appear to be stark COVID-19 disparities in the U.S. by race and ethnicity (Benitez, Courtemanche and Yelowitz, Forthcoming; Selden and Berdahl, 2020), where the causes are only partially explained by current economic, health, and transmission factors.

${ }^{2}$ That said, some other possible health consequences arising from the spread of the virus include reduced economic activity, less pollution, fewer car accidents, more drug use, more domestic violence, and less capacity in the health care system for non-COVID-19 issues, some of which certainly affects younger and healthier groups. Almond (2006) shows long-lasting consequences from the 1918 influenza pandemic. In addition, some of the precautions that individuals take against COVID-19 might also reduce the harm from other illnesses like influenza (Luhnow and Uribe, 2020).
} 
insurance pricing models by comparing the changes in premiums of policies offered to older individuals to those of policies offered to younger individuals. In addition, we compare the response of policies offered to relatively healthy younger individuals compared to relatively unhealthy older individuals (e.g., individuals in the lowest health category and those that smoke). This estimation approach allows us to difference out variation in pricing that might have occurred due to pandemic-induced changes in the bond and stock markets (which influence the profitability of life insurance products). In addition to analyzing changes in premiums, we also estimate the impact of the pandemic on policy offerings. Overall, the analysis shows that life insurance companies generally did not respond to the changes in mortality risk by increasing premiums or reducing policy offerings for those that experienced the greatest change in mortality risk. However, we do find evidence that policies with the lowest prices did differentially increase premiums for policies offered to older individuals. This implies that the lack of an overall response is caused in part by market competition. In addition, we find that policies offered to the oldest of the old (age $75+$ ) were differentially removed from the market consistent with (Hendren, 2013).

Although one might initially have expected large effects on life insurance premiums for the high-risk groups, several explanations - in addition to market competitionmay account for the lack of meaningful overall responses. First, life insurance premiums account for the rise in mortality, unconditional on the infection. Although the CFR or IFR is much higher than other illnesses like the flu, there have been unprecedented steps such as lockdowns and behavior changes that should reduce the probability of infection. Put differently, with extensive underwriting, there should be very little adverse selection from individuals who currently have COVID-19 being able to successfully obtain policies (Cawley and Philipson, 1999; Harris and Yelowitz, 2014) and conditional on not yet receiving the diagnosis, mortality risk has not significantly increased. ${ }^{3}$ Second, it is possible that even a "high-risk" life

\footnotetext{
${ }^{3}$ Early in the pandemic, life insurance companies rapidly changed their underwriting guidelines, postponing issuance of life insurance for applicants with a COVID-19 diagnosis or exposure. For example, as of
} 
insurance customer who purchases a policy listed in our data is quite different from those who are currently dying from COVID-19 in terms of mortality risk. To date, approximately 40 percent of deaths nationwide are from those residing in nursing homes (NYT, 2020), individuals who almost certainly would be rejected if applying for a new term life insurance policy. Recent commentary suggests that even accounting for excess deaths in New York City, the increased odds of death in 2020 for a 70-year-old are approximately 1 in 30 (Rosenkranz, 2020). Third, even sizable transitory increases in risk would reflect small increases in annual premium as the price increase is spread over the term of the policy (e.g., 15 years).

The paper is organized as follows. Section II gives an overview of the life insurance market and a theoretical model of pricing. Section III describes the Compulife data. Section IV presents the empirical specifications and results, and section V concludes.

\section{Background and Theory}

The fundamental purpose of life insurance is to protect family members - often surviving spouses - against earning losses due to a breadwinner's mortality (Harris and Yelowitz, 2018), although there are hybrid life insurance products that also serve other purposes such as tax planning and investing. Life insurance coverage in the U.S. is widespread, with approximately 70 percent of households having some form of life insurance coverage in either the individual or group markets (Harris and Yelowitz, 2017). The two markets differ in that individual market premiums are experience-rated with extensive underwriting, while group markets typically have some form of community rating and guaranteed issue. There is considerable discussion of adverse selection and asymmetric information in the individual term life insurance market (see Cawley and Philipson (1999); Harris and Yelowitz (2014); He (2009, 2011); Hedengren and Stratmann (2016)), and there are explicit mechanisms in contracts to discourage moral hazard (e.g., riders on suicide for the first several years).

April 2020, AIG would only consider applicants 30 days after a full recovery from COVID-19 and a return to previous health status (BUA, 2020). See https://www.buaweb.com/news/AIG-underwriting-updates.html. 
Life insurance markets have evolved over the years, and many companies offer premium quotes online, which in turn allows for lower search costs, greater comparison shopping, and more vigorous price competition (Brown and Goolsbee, 2002). Industry studies find that one-half of all adults sought life insurance information online in recent years, and nearly one-third attempted to purchase coverage. ${ }^{4}$ Although some features of term life insurance - such as a company's reputation and financial health - may enter into purchasing decisions, the key factors that contribute to annual premiums are the face value of the policy, term length, and probability of death proxied by measurable risk factors such as age, sex, underlying health, and risk behavior. Term life insurance policies would then appear to be much like a commodity, where policies from different companies are very close substitutes for each other, and in an online setting with comparison shopping, small premium adjustments may lead to leapfrogging, which in turn could dramatically affect demand. Of course, life insurance companies screen most customers extensively offline in the individual market (e.g., medical exams), potentially leading to reclassification risk (Handel, Hendel and Whinston, 2015), which is not observable in the data on policy offerings. In such a market, where there is clearly an exogenous increase in mortality for defined groups - such as those who are older and less healthy in 2020 (relative to earlier years and other groups) — we would expect larger premium increases. ${ }^{5}$ It is also possible for insurers to withdraw policies - essentially universal rejection for various groups - if the regulatory environment, competitive market pressure, or private information (Hendren, 2013) made premium increases infeasible. Of course, given that different companies make different projections about the overall aggregate risk from COVID-19, the magnitude of adjustment might be quite different. Nonetheless, it is hard to envision another market where the consequences of making a forecasting mistake are higher or where those making premium adjustments are more expert on mortality consequences.

\footnotetext{
${ }^{4}$ https://www.iii.org/fact-statistic/facts-statistics-life-insurance

5 "Premiums for life insurance and annuity products generally are not subject to regulatory approval, although regulators may seek to ensure that policy benefits are commensurate with the premiums charged." See https://www.naic.org/documents/consumer_state_reg_brief.pdf.
} 
To understand the influence of an increase in mortality risk on premiums, we use a basic model of term life insurance pricing in a competitive market where companies set premiums such that the expected net present value (ENPV) of premiums equals the ENPV of payouts from the company's perspective. ${ }^{6}$ The following equation presents the ENPV of total premiums, $D$, for level annual premiums, $d$.

$$
\operatorname{ENPV}(D)=d \sum_{t=0}^{T-1}\left[\beta^{t} \prod_{j=0}^{t}\left(1-\rho_{j}\right)\right]
$$

$T$ is the term length in years, $\beta$ is the discount factor, $\rho_{t}$ is the annual probability of death (with $\rho_{0}=0$ ). The equation merely discounts future premium payments and takes into account that annual premiums are only collected conditional on survival.

The next equation represents the expected net present value of costs, $C$, for a term life insurance policy with face value $v$.

$$
\operatorname{ENPV}(C)=v \sum_{t=1}^{T}\left[\beta^{t-1} \rho_{t} \prod_{j=1}^{t-1}\left(1-\rho_{j}\right)\right]
$$

Setting equation (1) equal to equation (2) and solving for the annual premium gives the following expression for term life insurance premiums

$$
d=v \frac{\sum_{t=1}^{T}\left[\beta^{t-1} \rho_{t} \prod_{j=1}^{t-1}\left(1-\rho_{j}\right)\right]}{\sum_{t=0}^{T-1}\left[\beta^{t} \prod_{j=0}^{t}\left(1-\rho_{j}\right)\right]}
$$

We use this simplified framework and resulting solution to get a sense of how large the premium response theoretically should be based on the expectation of a transitory shock to mortality risk. As inputs for one-year probability of death, we use general actuarial tables from the Social Security Administration. ${ }^{7}$ Based on the simplified model, a ten year $\$ 100,000$ term policy for a 60 -year old male, with a three

\footnotetext{
${ }^{6}$ See Mao et al. (2004) for an example of a more sophisticated life insurance pricing model. ${ }^{7}$ See https://www.ssa.gov/oact/STATS/table4c6.html.
} 
percent discount rate, would have an annual premium of $\$ 1,550 .^{8}$ If life insurance companies anticipated a ten percent increase in mortality risk for the first year of a policy, then the model implies a 0.9 percent increase in premiums (to $\$ 1,564$ ). Consequently, the one-year mortality shock elasticity of premiums is 0.09 for a 10 year term policy for a 60-year-old male. As the term of the policy increases, the responsiveness to an increase in the one-year mortality risk lessens. For example, holding all the other above conditions constant, the elasticity is $1.00,0.19,0.06$, and 0.04 for $1,5,15$, and 20-year policies, respectively. The elasticity is nearly identical for policies sold to different aged individuals.

If life insurance companies anticipated that the increased mortality risk would extend past the first year, then the responsiveness of term premiums significantly increases (e.g., 10-year term policy with two years of increased mortality has an elasticity of premiums of 0.20). Furthermore, the elasticity of premiums increases as the discount rate increases, but are unchanged with different face values.

Overall, the premium response of life insurance companies is contingent on the projected increase in mortality rates, the anticipated persistence of the increased risk, the term length, and discounting.

Using statistics on actual deaths involving COVID-19 and deaths from all causes as reported by the $\mathrm{CDC}$, the mortality rate for individuals aged 15 to 34 increased by 2.8 percent while the mortality rate for individuals aged 55 to 74 increased by 10.6 percent. ${ }^{9}$ Taken together with the elasticity, for a 10 -year term policy the model predicts that premiums would increase by 0.95 percent for a 60 -year-old and 0.25 percent for a 20-year-old. A back of the envelope calculation implies that an analysis comparing the old to the young would result in premiums differentially increasing by 0.70 percent for the old relative to the young.

\footnotetext{
${ }^{8}$ An annual premium of $\$ 1,550$ is higher than premiums offered for 60 -year old males listed on Compulife, except for individuals in "regular" health who are smokers. This difference in premiums is likely a result of life insurance companies not offering policies to individuals in "poor" and "very poor" health who greatly influence mortality rates for the general population captured in the Social Security actuarial tables.

${ }^{9}$ See https://www.cdc.gov/nchs/nvss/vsrr/covid_weekly/index.htm\#AgeAndSex. Accessed September 4,2020
} 


\section{Data}

We use data from Compulife to analyze the influence of the pandemic on life insurance premiums and offerings. ${ }^{10}$ Compulife is a quotation software used by life insurance agents to compare premiums and generate quotes for potential customers. We use monthly data from January 2014 to October 2020 from 95 companies and 804,242 unique policies. ${ }^{11}$ The Compulife database has information on at least one subsidiary for 19 out of the top 25 groups/companies in terms of market share. ${ }^{12}$

In addition to company and policy names, these data provide information on the general characteristics of the policy, including term length, face value, smoking status, health category (Regular, Regular Plus, Preferred, and Preferred Plus), gender, and age at purchase. New purchasers of life insurance taper off drastically for individuals older than 60 , with very few new policies initiated for individuals older than 70 (Harris and Yelowitz, 2014). Given the distribution of new purchasers, in the main analysis we specifically use data extracted on premiums and offerings for individuals from age 20 to 70 in five-year increments (i.e., $20,25, \ldots, 70){ }^{13}$

Premiums vary both based on the company issuing the policy and policy characteristics. Nonetheless, the vast majority of premium variation is based on general characteristics. A model that regresses the general characteristics (indicators for age, health category, term, face value, etc.) on log premiums has an R-squared of $0.98 .^{14}$

In the main analysis, we restrict the data to common term lengths, including

\footnotetext{
${ }^{10}$ See Cawley and Philipson (1999), Hendel and Lizzeri (2003), Cox et al. (2013), and Koijen and Yogo (2015) for additional studies that conduct analysis using Compulife data.

${ }^{11}$ To enhance the data quality, we make some minor corrections and remove outliers as outlined in Appendix A.

${ }^{12}$ The National Association of Insurance Commissioners reports on the top groups/companies in terms of market share for life insurance in 2019. See https://www.naic.org/documents/web_market_share_life_ fraternal.pdf?81. Compulife data do not contain information on Dai-Ichi Life Holdings Inc Group, Globe Life Inc Group, Metropolitan Group, Penn Mutual Group, State Farm Group, or Voya Financial Group during the main analysis period. The report on market share does not differentiate based on product type, which explains the omission of, for example, Voya Financial group as it sells employer-sponsored life insurance but does not sell individual term life insurance.

${ }^{13}$ Policies offered for common term lengths (e.g., 10, 15, and 20 years) dwindle significantly for policies offered to individuals older than 70 with only one-year term policies available for 85 -year-old individuals.

${ }^{14} \mathrm{~A}$ model that excludes the indicator for smoking has an R-squared of 0.93 , and a model that excludes health status has an R-squared of 0.97 . The R-squared is insensitive to the exclusion of observations from 2020 .
} 
10, 15, and 20-year term policies, which reduces the total policy count to 602,578 policies. Of those unique policies, 394,549 policies started being offered and were removed in the sample window with only 49,752 policies active for the entire 82 months. For the 216,362 policies that were offered in January 2014, 88 percent were active one-year later with 70 percent still active after two years. By 2020 only 27 percent of those initially in the sample were offered on Compulife. Overall, the median duration of a policy being offered is 15 months.

Firms that actively change their policy offerings might be more likely to be responsive to changes in expected mortality resulting from the pandemic. To gauge the premium change activity level in a company, we analyze the frequency of premium adjustments from 2014 to 2019, prior to the pandemic. We analyze policies that are offered for more than 13 months to capture annual price adjustments. As our metric for premium change activity, we use the proportion of policies that experienced a premium change over a year. The median company altered 10.4 percent of their policies' premiums with an average of 26.4 percent. We define a company as active if they are in the upper quartile of premium change activity ( $>42.2$ percent).

In addition to actively changing premiums, a company might respond to variations in the market or risk by no longer offering a particular policy and potentially replacing it with a new one. Hendren (2013) notes that in some contexts, including life insurance, companies choose not to sell insurance to potential customers who have certain observable, often high-risk characteristics. Such rejections, potentially withdrawing policies in our context, can be explained by private information, where premium adjustments are not sustainable. To measure activity on this extensive margin, we aggregate the number of times a company changes a policy offering (i.e., add or drop a policy) annually. We then take the ratio of the median annual changes to the median number of policies offered. ${ }^{15}$ Over a year, the median company altered the equivalent of 14.6 percent of their median policies offerings. We

\footnotetext{
${ }^{15}$ We do not count initial inclusion or exit from Compulife as changes as we do not know if the policies were already in effect or if they continue after the company stopped listing with Compulife. In a company is only listed for a portion of a year, we scale the changes assuming the observed months are typical of the year.
} 
define a company as being active in offerings if the company is in the top quartile of alterations (greater than 49.5 percent). ${ }^{16}$

\section{Empirical Analyses}

\section{A. Premium Adjustments}

Prior to estimating a formal regression, we first plot changes in premiums over time. To do this, we first create an index to normalize premiums such that modifications can be viewed as percent changes. The premium index for policy $i$ in time $t$ is given by:

$$
\text { Premium_Index }_{i t}=\frac{\text { Annual_Premium }_{i t}}{\text { Annual_Premium }_{i t_{0}}} \times 100
$$

Where $t_{0}$ is the premium in the first month of the estimation sample. We then get a measure of premiums at the company level (Premium_Index $x_{j t}$ ) by averaging the premium index (Premium_Index $x_{i t}$ ) across all policies within a company. The main reason to use the average index rather than an average of premiums is that policies with larger premiums (e.g., higher face values) would implicitly receive more weight in an average of the premiums. A change in the index represents the average percent change in premiums rather than the change in dollar amounts.

Figure 1a plots the average of the company premium indexes for a balanced panel of policies offered from January 2019 until October 2020. ${ }^{17}$ The figure shows minimal changes in average premiums from January 2019 to October 2020. There is a small overall increase in the average premium index in 2020, which would be consistent with a premium response to COVID-19. Nonetheless, the most substantial increase in the index occurs from November to December 2019, which predates meaningful news of the pandemic. ${ }^{18}$

\footnotetext{
${ }^{16}$ There is a weakly positive correlation between the two activity metrics (0.15) indicating some companies that both actively adjust premiums and actively alter offerings with the majority of active companies primarily focusing on one or the other.

${ }^{17}$ For this balanced panel, there are 62 companies and 103,975 policies.

${ }^{18}$ Premiums for a given month are released the first of the month. Consequently, changes in premiums in December 2019 would predate the earliest news of COVID-19.
} 
To better understand any change in premium in 2020, we investigate further and narrow the sample window to December 2019 to October 2020. Of the 74 companies that continuously offered policies for the shorter window, 55 did not change premiums and only 12 had higher premium indexes in October 2020 relative to December 2019. Table 1 reports the changes for companies that altered premiums from December 2019 to October 2020. As shown, the increase in premiums is attributed mainly to the premium changes of three out of 74 companies analyzed for the table.

Theory would suggest that life insurance companies would be most likely to adjust premiums for the demographic that experienced the greatest change in mortality risk and that companies would be less likely to increase premiums for demographics that do not experience significant changes in mortality risk. With this in mind, Figure $1 \mathrm{~b}$ plots the change in premiums for the oldest individuals in the main sample in comparison to younger individuals whose mortality is less affected by the virus. Mortality rate changes from COVID-19 gradually increase (at an increasing rate) with age. Consequently, we exclude policies offered to individuals aged 40 to 55 in these figures as well as the regression analysis to compare individuals that experienced modest changes in mortality risk to individuals that experienced much greater increases from COVID-19. ${ }^{19}$ As shown in the figure, the increase in premiums in 2020 occurred more for younger individuals than the older individuals, inconsistent with a COVID-19 explanation.

In addition to age, COVID-19 disproportionately increases the risk for individuals who have pre-existing conditions or smoke. Figure 1c compares the change in premiums for older individuals in the worst health category (Regular) that smoke to younger individuals in the best health categories (Preferred and Preferred Plus) that do not smoke. As shown, the premiums for high-risk older consumers do not experience any meaningful change from January to September 2020, whereas there is a slight increase in the early months of 2020 for low risk younger policies. Overall, these figures do not provide any compelling evidence of changes in premiums caused

\footnotetext{
${ }^{19}$ The main empirical findings are not sensitive to this exclusion with only marginal changes to the point estimates.
} 
by COVID-19.

Our formal empirical strategy relies on the assumption that premium increases should differentially occur for older individuals who face higher mortality risk from COVID-19. To estimate the impact of COVID-19 on life insurance premiums, we use the following event study specification.

$$
\log \left(\operatorname{Premium}_{i t}\right)=\alpha_{i}+\gamma_{t}+\sum_{s} \beta_{s} \text { Older }_{i} \times 1[s=t]+\varepsilon_{i t}
$$

where $\log \left(\right.$ Premium $\left._{i t}\right)$ is the $\log$ of annual premiums for policy $i$ in month $t$ and Older $_{i}$ is an indicator for policies offered to individuals aged 60,65, or 70. $\alpha_{i}$ and $\gamma_{t}$ respectively represent policy and month/year fixed effects. The coefficients of interest are $\beta_{s}$, which represent the monthly treatment effects relative to the base month of December 2019 (directly before the earliest information about COVID19). If the monthly treatment effects are positive for months in 2020, then there is evidence that life insurance companies differentially increased premiums for the old relative to the young. Any statistical significance for months in 2019 would indicate potential violations of the parallel trends assumption. Standard errors are clustered at the company level to account for coordinated pricing strategies inside a company.

Figure 2 illustrates the finding from the main event study. As shown, there is no evidence of differential increases in premiums for the old relative to the young. Also, the point estimates prior to COVID are statistically insignificant, which provides evidence supporting the parallel trends assumption.

Table 2 reports the findings of several subsample analyses with the main dependent variables being interactions of months in 2020 with an indicator for the policy being sold to older individuals (age 60 to 70 ). ${ }^{20}$ Specifically, we analyze companies that have the largest market shares, companies that are the most active in terms of modifying premiums and offerings, and those with different AM Best ratings. Across

\footnotetext{
${ }^{20}$ Similar results are found if we estimate a full event study with interactions for the months in 2019 as well.
} 
each of these subgroups, there is not a statistically significant increase in premiums for the old relative to the young. (Companies that actively changed premiums actually marginally decreased prices for the old relative to the young in February and March.) The latter two columns of Table 2, use additional variation in health status that theoretically could differentially increase premiums. For both of these specifications we use policies sold to younger non-smokers in the best health categories as the control group. For the treatment group we use older individuals in the worst health category and older individuals in the worst health category that also smoke for the treatment groups respectively. The only statistically significant premium effect is observed in September and October of 2020 for the specification that uses policies sold to relatively unhealthy older smokers as the treatment group. Nonetheless, the result is small - less than one percent - and only marginally significant at the 90 percent level.

The theoretical model predicts that shorter-term policies should, all else equal, have larger responses to temporary mortality shocks. Also, it is reasonable to assume that companies might be more sensitive regarding policies with higher face values as they represent larger potential losses per policy. Consequently, we analyze and present policies stratified by term length and face value in Table 3. Across each of the specifications, there is no evidence that COVID-19 caused differential increases in premiums for the old relative to the young. Of the 100 event study coefficients presented in this table, virtually all are "wrong-signed" (negative), with point estimates very close to zero (often changes of 0.4 percent or less), with standard errors that preclude the possibility of large premium increases.

One possible explanation for the lack of response in premiums from the pandemic is that market competition prevents companies from increasing premiums. Conditional on policy characteristics (face value, term length, etc.) and applicant risk (age, sex, health, etc.), life insurance very much resembles a commodity, where consumers are likely to be extremely sensitive to price. To explore this possibility, we analyze if there are differential responses by low-price leaders and other market participants. We restrict the sample to companies with either $\mathrm{A}++$ or $\mathrm{A}+\mathrm{AM}$ Best Ratings to 
decrease the chances that differences in premiums are a result of different likelihoods of default. Within a particular product type (e.g., 15-year term, age 30, male, nonsmoker, preferred health), the median difference between the lowest price and the second-lowest price is 1.2 percent (mean of 5.2 percent) with 22.6 percent of unique product types having at least two firms that offer the lowest price. If the low price leader increased premiums such that their product was no longer the cheapest, then they could lose a considerable share of price-sensitive customers. Alternatively, it could be argued that firms with the low price advantage have a small amount of latitude to increase their premiums without as much concern for losing customers.

Products that do not have the low price advantage and compete across different dimensions (e.g., customer service, additional riders, etc.) might have more flexibility to increase their prices in response to the pandemic. Alternatively, those without a price advantage might be unwilling to increase their price as there already exists cheaper options for their potential customers.

To analyze if life insurance policies with the low price behave differently, we estimate regression models that limit the sample based on the product's price ordering in December 2019, immediately before the first news of COVID-19. Table 4 presents results first for policies that did not offer the lowest premium within a given product type and shows no statistically significant response. The second column reports results for analysis using only policies that offer the lowest within product premium. For this subset of policies, there is a statistically significant increase in premiums for policies offered to an older group relative to policies offered to younger individuals with point estimates implying that annual premiums raised by 0.2 to 0.8 percent between March and October 2020. The last column further restricts the sample to policies that had the low price advantage, with the next lowest premium being at least one percent more expensive. Consistent with the gap allowing for more adjustments, the premium for policies offered to older individuals increased more relative to changes in premiums offered to younger individuals with the highest monthly effect of a 1.3 percent relative increase in premiums. In both of the lowest price specifications, there were not statistically significant responses in the early months 
of 2020 consistent with the timing of information on COVID-19 and its likely effects on U.S. residents.

Overall, the results imply that the premium response was minimal due to COVID19, with some evidence that price competition inhibited life insurance companies from adjusting their premiums in response to increased mortality risk.

\section{B. Policy Offerings}

Rather than changing premiums for a policy that became riskier due to COVID19, companies could have responded by not offering the policy to new customers. There do not appear to be any regulatory hurdles to discontinue offering a policy to new customers. Given the looming uncertainty surrounding COVID-19 that makes products difficult to price, this option might be attractive for policies targeting demographics at a higher risk of death from COVID-19.

In an innovative study, Hendren (2013) explores circumstances under which insurance companies reject applicants rather than adjusting premiums. In our context, with the changing mortality risk with COVID-19 in 2020 relative to earlier years, withdrawing life insurance offerings for applicants with observable characteristics such as older age or poorer health is creating a new "rejection" group. Hendren argues that private information known by potential applicants - beyond what can be captured by their observable characteristics - has a key role in such rejections. Much like Hendren's motivation with long-term care insurance, there are specific factors and preferences related to the pandemic - such as the ability or willingness to be vigilant about COVID-19 safety - that are difficult for an insurance company to obtain and verify.

Indeed, underwriting guidelines did change in recognition of the pandemic (BUA, 2020). Companies generally postponed offerings (e.g., created new rejection groups) based on a combination of age, health status, and face value. For example, AIG postponed issuance of policies for those over age 75, and for those aged 66-75 inclusive of "medical flat extras" (essentially risks that the standard rating tables do not cover). 
We once again analyze 10, 15, and 20-year term policies from January 2019 to October 2020. If a company either starts or stops listing policies on Compulife, we do not have data on any of their policy offerings. We hesitate to assume that all of the policies were discontinued if not listed on Compulife. Consequently, we restrict the analysis to the 78 companies that continuously listed policies on Compulife during the sample period. ${ }^{21}$

Figure 3 plots the proportion of all policies that were active for each month based on age groups. As shown, there is a slight decrease in offerings for younger individuals over time, whereas there is a larger decrease in offerings to older individuals. Nonetheless, the decrease in net policies offered to older individuals begins prior to any news of COVID-19.

To estimate the impact of COVID-19 on offerings formally, we use an event study specification analogous to the model used to estimate the pandemic's influence on premiums.

$$
\text { Active }_{i t}=\alpha_{i}+\gamma_{t}+\sum_{s} \beta_{s} \text { Older }_{i} \times 1[s=t]+\varepsilon_{i t}
$$

Where Active $_{i t}$ is an indicator for a company offering policy $i$ on Compulife at time $t$.

Figure $4 \mathrm{a}$ presents the results of the base specification. While the point estimates are statistically significant (at the 90-percent level) and negative in 2020, consistent with a COVID-19 effect, there is also evidence of a pre-trend, which violates a main assumption of the analysis. To control for this pre-trend, we first estimate a model with Active as the dependent variable and age-group fixed effects (i.e., older and younger) and age-group by month trends using data from the pre-period, January 2019 to December 2019 (Kleven et al., 2014). We generate residuals for the full time period using the estimated coefficients and then use these residuals as the dependent variable for the event study presented in Figure $4 \mathrm{~b} .{ }^{22}$ As shown, after controlling for

\footnotetext{
${ }^{21}$ We also require that a policy be offered at least once in the sample period.

${ }^{22}$ We use this method rather than directly including a group by month trend in the specification, as the group by year trend could absorb any potential treatment effect, thus attenuating any result.
} 
linear pre-trends, there is no statistically significant evidence of differential policy removal for the old relative to the young due to the pandemic.

Table 5 presents the results for several different subsets, with each specification accounting for a linear pre-trend as described above. In the table, the only subsample analysis that indicates differential decreases in offerings for the elderly is the subset of companies that modify premiums most regularly. The largest relative decrease occurs in July and indicates that offerings decreased by 5.1 percentage points due to COVID-19. Nonetheless, in the next reported specification that analyzes companies that actively change offerings, there is evidence that offerings differentially increased from August to October 2020 for the elderly.

Table 6 further analyzes changes in offerings based on term length and face value. Stratifying by term length does not change the main findings. However, there is some evidence that companies differentially decreased policy offerings for the largest face value policies ( $\geq \$ 1$ million). For $\$ 1$ million term policies, offerings decreased for the elderly by $1.7,1.7$, and 3.1 percentage points, respectively for May, June, and July 2020. This decrease in the largest face value policies could represent increased scrutiny of policies that could represent the biggest losses for a company.

Overall, the offerings analysis indicates that the pandemic did not cause widespread adjustments to offerings.

\section{The New York Market}

In the main analysis, we use quotes from the entire U.S. In general, companies offer the same life insurance policy to residents of all or almost all states, which limits analysis that uses geographic variation in the pandemic's severity. New York, however, presents an interesting case study as it was harder-hit early on by the pandemic and also because the life insurance regulatory structure leads to subsidiaries being created specifically to offer policies to residents of New York (Pottier and Sommer, 1998).

We analyze policies that were offered in New York but not in New Mexico to isolate policies that have a greater potential to respond to the early effects of COVID-19 
specific to New York. ${ }^{23}$ Table 7 presents the results for both changes in premiums and offerings. As illustrated, life insurance companies did not increase premiums or differentially discontinue policies offered to older individuals, consistent with the main analysis. ${ }^{24}$ These results indicate that companies did not significantly alter premiums or offering even in localities that were impacted the most early on in the pandemic.

\section{Policies Listed for the Oldest of the Old}

The main sample includes policies sold to individuals between the ages of 20 and 70 , which captures the vast majority of commonly purchased policies (Harris and Yelowitz, 2014). In this subsection, we analyze the response for policies sold to individuals aged 75,80 , and 85 , who experience the greatest increase in mortality risk due to COVID-19. Given the large mortality risk, both the number of policies and companies offering policies are comparatively small for these advanced ages. ${ }^{25}$

For analysis of premium changes for policies sold to individuals aged 75 through 85 compared to policies sold to younger individuals (aged 20-35), we find no significant response to COVID. However, when we analyze policy offerings, we find that offerings significantly decreased for the oldest age group starting in May 2020, as shown in Figure 5. In contrast to the null result for the main specification, this oldest group experienced significant decreases with point estimates implying that the oldest policies offerings differentially decreased in July by 15.8 percentage points for the sample using 10, 15, and 20-year term policy and by 13.6 percentage points for one, five, and 10-year policies (more typical term lengths for the oldest age groups). These large results indicate that companies decreased offerings to the most vulnerable, but it likely influenced a small minority of atypical purchasers.

\footnotetext{
${ }^{23}$ We selected New Mexico because it is the default state in the Compulife software.

${ }^{24}$ For the policy offerings specification in May through July 2019, the point estimates are statistically significant at the 90 percent level, indicating a potential violation of the parallel trends assumption. Accounting for linear pre-trends, as in the main analysis, exacerbates the issue. When we account for both linear and quadratic pre-trends, the results continue to indicate a absence of a statistically significant effect in 2020 (as well as 2019).

${ }^{25}$ Appendix Figure A2 illustrates the distribution of policies and the number of companies that offer policies by age.
} 


\section{Conclusion}

The coronavirus pandemic has created unparalleled short-run disruption across virtually every segment of society, both in the US and elsewhere. If the earliest predictions of the increase in mortality rate from COVID-19 would have come to fruition, then theory suggests that life insurance companies would have been forced to significantly adjust life insurance premiums or offerings to account for the increased risk. Our findings - from an analysis starting with nearly 100 companies and 800,000 policies - suggest minimal observable adjustments through October 2020. Nonetheless, we do find evidence that low price leaders raised premiums in response to increased mortality risk, and policies offered to individuals age 75 and above were differentially removed from the market. Overall, these results are consistent with a combination of market competition in life insurance and anticipation of meaningful precautionary behavior to contain the spread among the vulnerable, leading to only modest short-run increases in mortality risk.

Our expectation is that market-driven adjustments in the life insurance industry represent some of the most informed expectations on the path of the pandemic. Nonetheless, our findings of relatively small adjustments in the term life insurance market - perhaps unexpected - should not be interpreted as dismissing the individual risk from COVID-19, especially for more vulnerable members of society. Although there are a host of reasons that could explain our results, the most likely one is that as of early November 2020, there have been approximately 9.7 million confirmed cases and 235,000 fatalities in the U.S., in a country with 330 million individuals and 2.8 million annual deaths. The most dire mortality forecasts - using

either the CFR or IFR - rely on much larger percentages of the population being infected.

Accompanying the "third surge" in cases is the real promise of widespread distribution of an effective vaccine in the next few months. The potential vaccine, along with our findings, suggest that it is unlikely that life insurance companies will significantly alter policies in the next several months due to COVID-19. 


\section{REFERENCES}

Abbott, Brianna, and Jason Douglas. 2020. "How Deadly Is COVID19? Researchers Are Getting Closer to an Answer." The Wall Street Journal, https://www.wsj.com/articles/how-deadly-is-covid-19-researchers-aregetting-closer-to-an-answer-11595323801?mod=hp_lead_pos5.

Almond, Douglas. 2006. "Is the 1918 Influenza Pandemic Over? Long-term Effects of in Utero Influenza Exposure in the Post-1940 Us Population." Journal of Political Economy, 114(4): 672-712.

Beigel, John H, Kay M Tomashek, Lori E Dodd, Aneesh K Mehta, Barry S Zingman, Andre C Kalil, Elizabeth Hohmann, Helen Y Chu, Annie Luetkemeyer, Susan Kline, et al. 2020. "Remdesivir for the treatment of Covid-19preliminary report." New England Journal of Medicine.

Benitez, Joseph, Charles Courtemanche, and Aaron Yelowitz. Forthcoming. "Racial and Ethnic Disparities in COVID-19: Evidence from Six Large Cities." Journal of Economics, Race, and Policy, https://doi.org/10.1007/s41996020-00068-9.

Brown, Jeffrey R., and Austan Goolsbee. 2002. "Does the Internet Make Markets More Competitive? Evidence from the Life Insurance Industry." Journal of Political Economy, 110(3): 481-507.

BUA. 2020. "COVID-19 Life Insurance Carrier Updates." https://www.buaweb. com/pages/COVID-19-Life-Updates.html, accessed November 9, 2020.

Cawley, John, and Tomas Philipson. 1999. "An Empirical Examination of Information Barriers to Trade in Insurance." American Economic Review, 89(4): 827-846.

CDC, U.S. Centers for Disease Control, and Prevention. 2020. "People Who Are at Higher Risk for Severe Illness - CDC." @CDCgov. Last Modified 
2020-05-14T05:59:39Z. https://www.cdc.gov/coronavirus/2019-ncov/need-extraprecautions/people-at-higher-risk.html.

Corum, Jonathan, Denise Grady Sui-Lee Wee, and Carl Zimmer. 2020. "Coronavirus Vaccine Tracker." The New York Times.

Courtemanche, Charles, Joseph Garuccio, Anh Le, Joshua Pinkston, and Aaron Yelowitz. 2020. "Strong Social Distancing Measures in the United States Reduced the Covid-19 Growth Rate: Study Evaluates the Impact of Social Distancing Measures on the Growth Rate of Confirmed Covid-19 Cases across the United States." Health Affairs, 39 (7): 1237-1246.

Cox, Samuel H, Yijia Lin, Ruilin Tian, and Luis F Zuluaga. 2013. "Mortality Portfolio Risk Management." Journal of Risk and Insurance, 80(4): 853-890.

Ericson, Keith Marzilli, and Justin Sydnor. 2017. "The Questionable Value of Having a Choice of Levels of Health Insurance Coverage." Journal of Economic Perspectives, 31(4): 51-72.

Ferguson, Neil, Daniel Laydon, Gemma Nedjati Gilani, Natsuko Imai, Kylie Ainslie, Marc Baguelin, Sangeeta Bhatia, Adhiratha Boonyasiri, ZULMA Cucunuba Perez, Gina Cuomo-Dannenburg, et al. 2020. "Report 9: Impact of Non-pharmaceutical Interventions (NPIs) to Reduce Covid19 Mortality and Healthcare Demand."

Friedson, Andrew I, Drew McNichols, Joesph J Sabia, and Dhaval Dave. 2020. "Did Californias Shelter in Place Order Work? Early Evidence on Coronavirus-related Health Benefits." National Bureau of Economic Research, https://doi.org/10.3386/w26992. http://www.nber.org/papers/w26992.

Handel, Ben, Igal Hendel, and Michael D Whinston. 2015. "Equilibria in Health Exchanges: Adverse Selection Versus Reclassification Risk." Econometrica, 83(4): 1261-1313. 
Harris, Timothy F., and Aaron Yelowitz. 2014. "Is there Adverse Selection in the Life Insurance Market? Evidence from a Representative Sample of Purchasers." Economics Letters, 124(3): 520-522.

Harris, Timothy F., and Aaron Yelowitz. 2017. "Nudging Life Insurance Holdings in the Workplace." Economic Inquiry, 55(2): 951-981.

Harris, Timothy F, and Aaron Yelowitz. 2018. "Life Insurance Holdings and Well-being of Surviving Spouses." Contemporary Economic Policy, 36(3): 526538.

He, Daifeng. 2009. "The Life Insurance Market: Asymmetric Information Revisited." Journal of Public Economics, 93(9-10): 1090-1097.

He, Daifeng. 2011. "Is There Dynamic Adverse Selection in the Life Insurance Market?" Economics Letters, 112(1): 113-115.

Hedengren, David, and Thomas Stratmann. 2016. "Is there Adverse Selection in Life Insurance Markets?" Economic Inquiry, 54(1): 450-463.

Hendel, Igal, and Alessandro Lizzeri. 2003. "The Role of Commitment in Dynamic Contracts: Evidence from Life Insurance." Quarterly Journal of Economics, 118(1): 299-328.

Hendren, Nathaniel. 2013. "Private Information and Insurance Rejections." Econometrica, 81(5): 1713-1762.

Hsiang, Solomon, Daniel Allen, Sébastien Annan-Phan, Kendon Bell, Ian Bolliger, Trinetta Chong, Hannah Druckenmiller, Luna Yue Huang, Andrew Hultgren, Emma Krasovich, et al. 2020. "The Effect of Large-scale Anti-contagion Policies on the Covid-19 Pandemic." Nature, 1-9.

Kleven, Henrik Jacobsen, Camille Landais, Emmanuel Saez, and Esben Schultz. 2014. "Migration and Wage Effects of Taxing Top Earners: Evidence from the Foreigners Tax Scheme in Denmark." Quarterly Journal of Economics, 129(1): 333-378. 
Koijen, Ralph SJ, and Motohiro Yogo. 2015. "The Cost of Financial Frictions for Life Insurers." American Economic Review, 105(1): 445-75.

Luhnow, David, and Alice Uribe. 2020. "Covid-19 Measures Have All but Wiped Out the Flu in the Southern Hemisphere." The Wall Street Journal, https://www.wsj.com/articles/covid-19-measures-have-all-butwiped-out-the-flu-in-the-southern-hemisphere-11595440682.

Lyu, Wei, and George L Wehby. 2020. "Shelter-in-place Orders Reduced Covid19 Mortality and Reduced the Rate of Growth in Hospitalizations: Study Examine Effects of Shelter-in-places Orders on Daily Growth Rates of Covid-19 Deaths and Hospitalizations Using Event Study Models." Health Affairs, 10-1377.

Mandavilli, Apoorva. 2020. "Federal Officials Turn to a New Testing Strategy as Infections Surge." The New York Times, https://www.nytimes.com/2020/07/01/ health/coronavirus-pooled-testing.html.

Mao, Hong, James M Carson, Krzysztof M Ostaszewski, and Luo Shoucheng. 2004. "Pricing Life Insurance: Combining Economic, Financial, and Actuarial Approaches." Journal of Insurance Issues, 134-159.

NYT. 2020. "More Than 40Nursing Homes." The New York Times, https://www. nytimes.com/interactive/2020/us/coronavirus-nursing-homes.html.

Pottier, Steven W, and David W Sommer. 1998. "Regulatory stringency and New York licensed life insurers." Journal of Risk and Insurance, 485-502.

Rosenkranz, Robert. 2020. "The Measure of New York's Coronavirus Devastation." Wall Street Journal, https://www.wsj.com/articles/the-measure-of-newyorks-coronavirus-devastation-11591140254.

Scism, Leslie. 2020. "Less Driving, Fewer Accidents: Car Insurers Give Millions in Coronavirus Refunds." The Wall Street Journal, https://www.wsj.com/articles/car-insurer-american-family-gives-200-million-incoronavirus-refunds-as-accidents-decline-11586175602. 
Selden, Thomas M, and Terceira A Berdahl. 2020. "COVID-19 and Racial/ethnic Disparities in Health Risk, Employment, and Household Composition: Study Examines Potential Explanations for Racial-ethnic Disparities in Covid-19 Hospitalizations and Mortality." Health Affairs, 10-1377.

Verity, Robert, Lucy C Okell, Ilaria Dorigatti, Peter Winskill, Charles Whittaker, Natsuko Imai, Gina Cuomo-Dannenburg, Hayley Thompson, Patrick GT Walker, Han Fu, et al. 2020. "Estimates of the Severity of Coronavirus Disease 2019: A Model-based Analysis." The Lancet Infectious Diseases. 
Figure 1. Average Company Premium Changes

(a) Combined

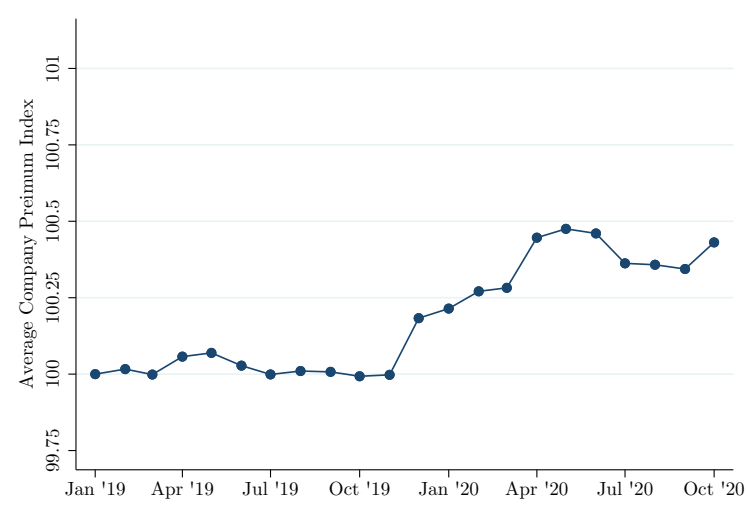

(b) By Age

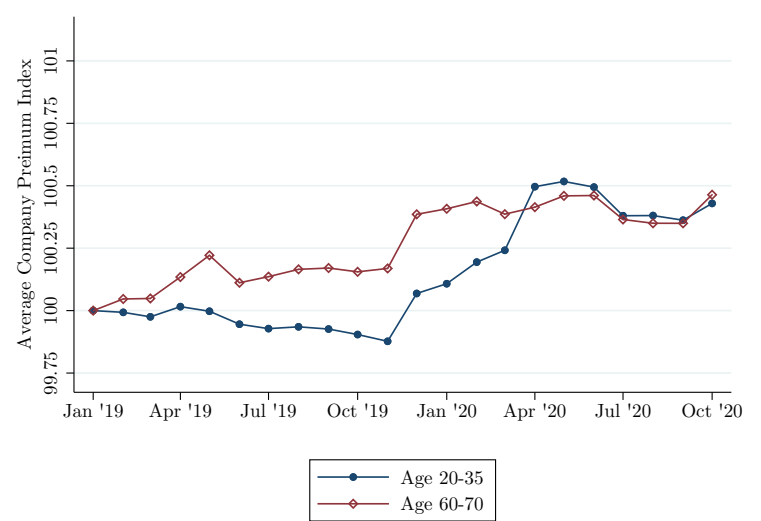

(c) By Risk/Age

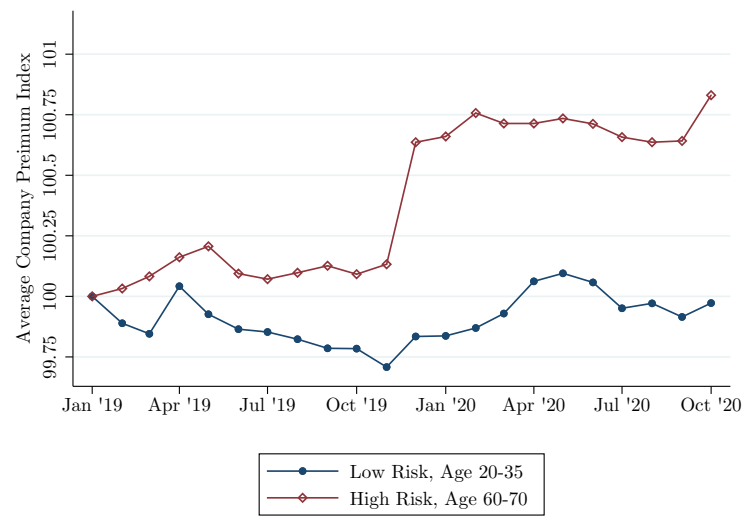

Note: The figure presents the average company premium index from January 2019 to July 2020 originating from a balanced panel of 10, 15, and 20-year term policies that were continuously offered from July 2019 until October 2020. Low Risk is defined as individuals in the worst health category (Regular) that smoke and High Risk is defined as individuals in the best health categories (Preferred and Preferred Plus) that do not smoke. 
Figure 2. Event Study, Influence of COVID on Log Premiums
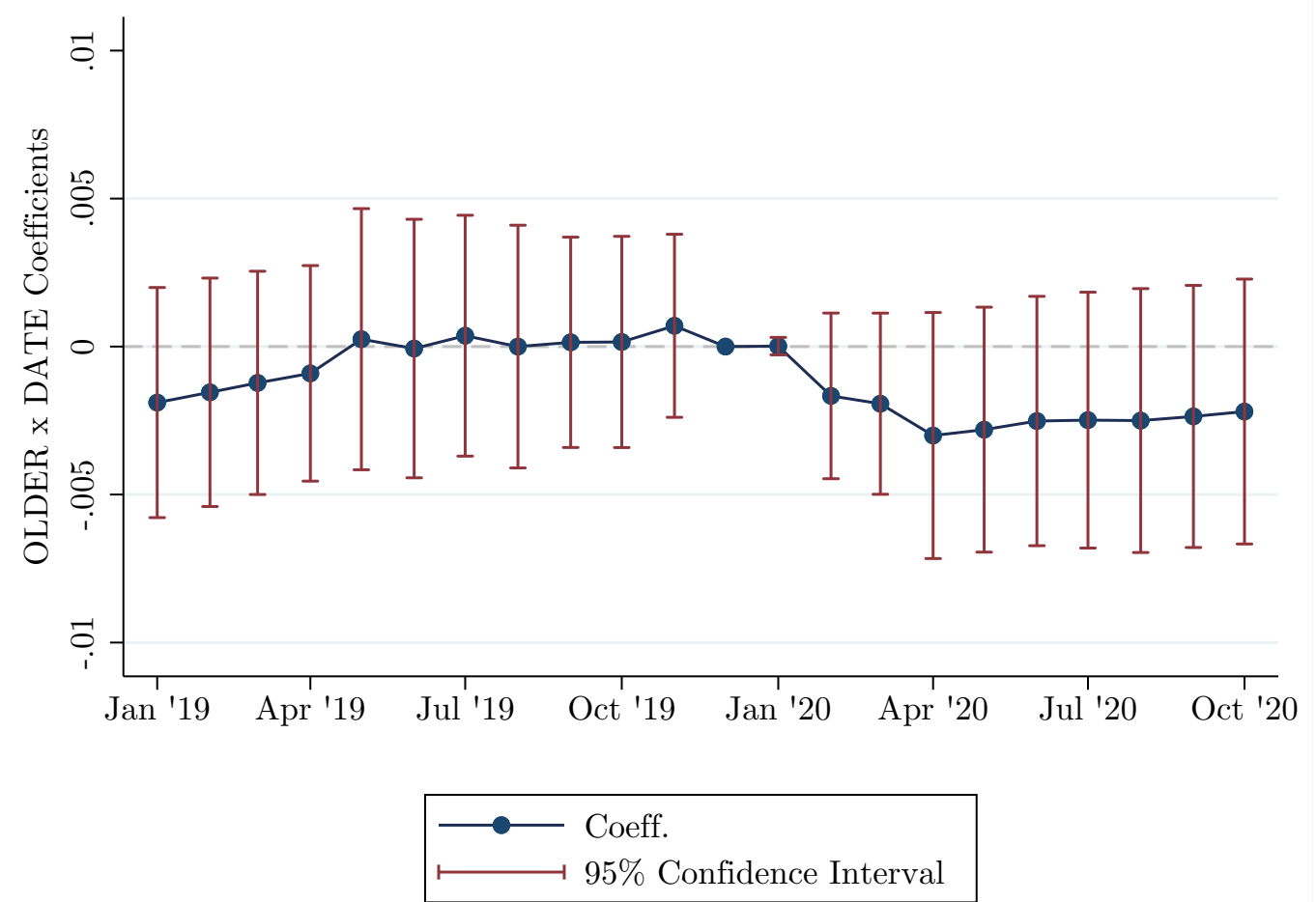

Note: The unbalanced panel includes 10, 15, and 20-year term policies listed on Compulife from January 2019 to October 2020 that were offered to individuals aged 20, 25, 30, 35, 60, 65, and 70. There were 207,582 unique policies from 93 companies and 2,733,128 total observations. Controls included policy and month fixed effects and standard errors were clustered at the company level. 
Figure 3. Proportion of Policies Offered by Month and Age Group
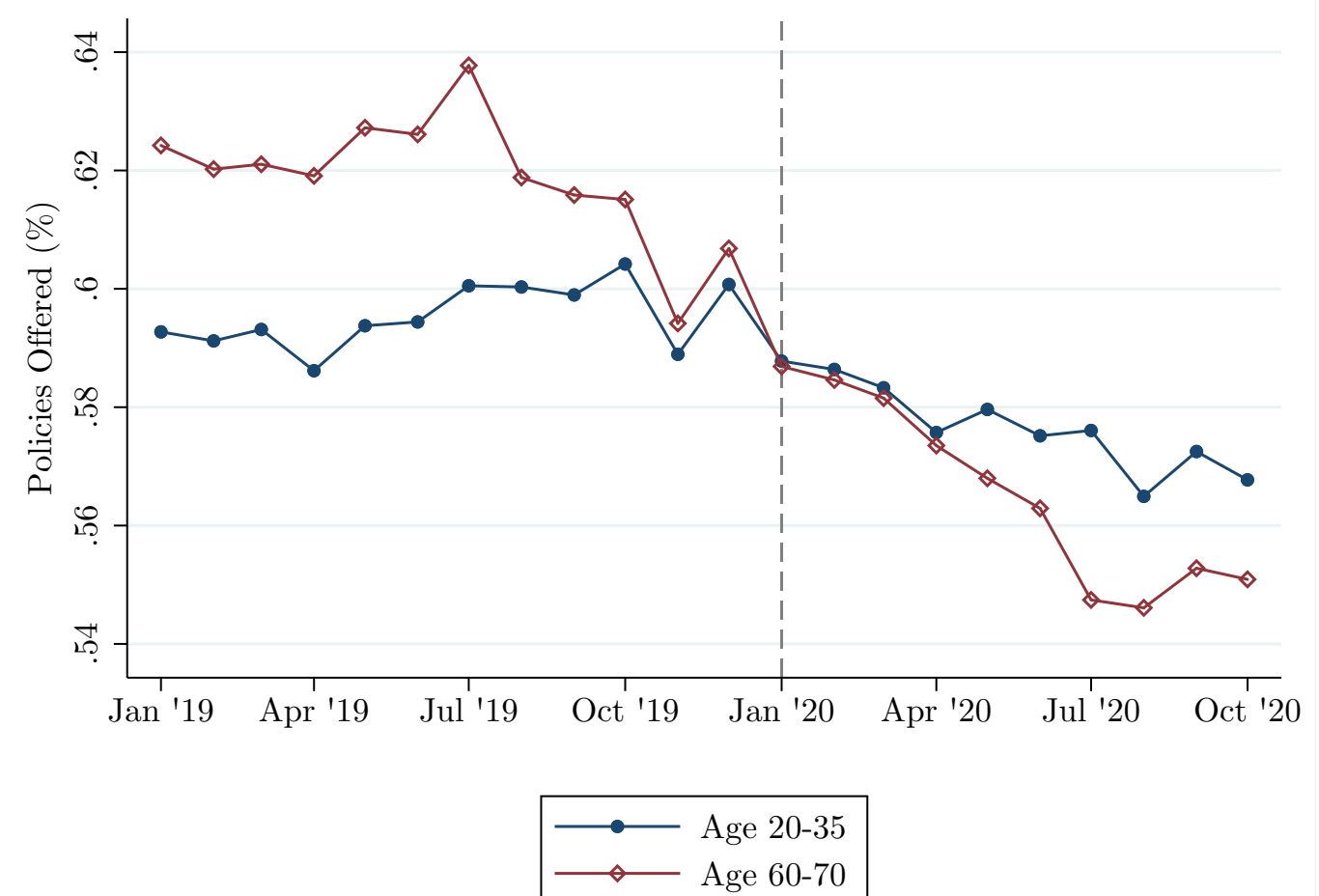

Note: The figure shows the proportion of the 197,268 unique policies that were actively offered on Compulife for the 78 companies that continuously listed policies on the platform from January 2019 to October 2020 by age group. 
Figure 4. Event Study, Influence of COVID on Offerings

(a) Base Specification

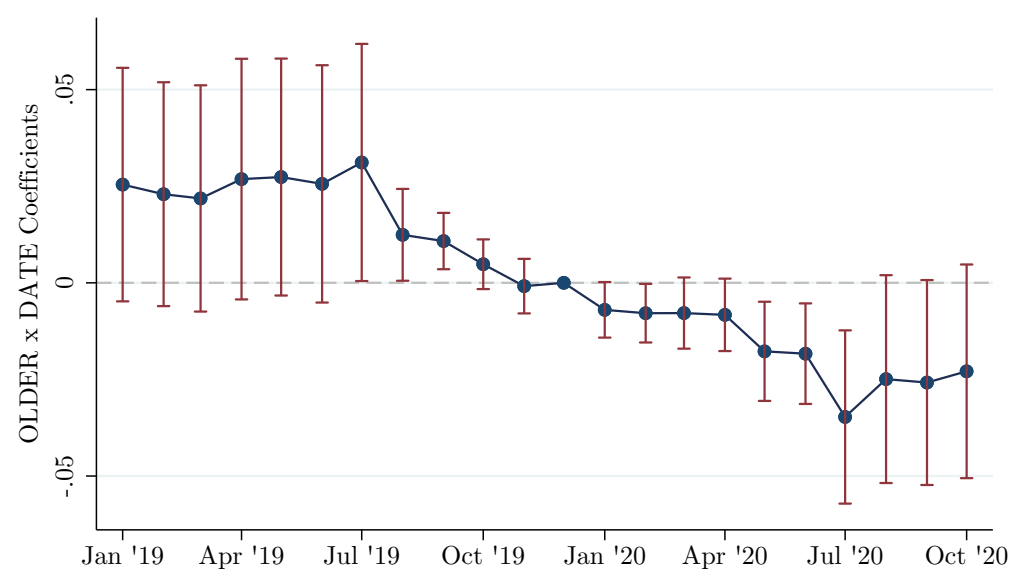

$\longrightarrow$ Coeff.

95\% Confidence Interval

(b) Controlling for Linear Pre-Trends
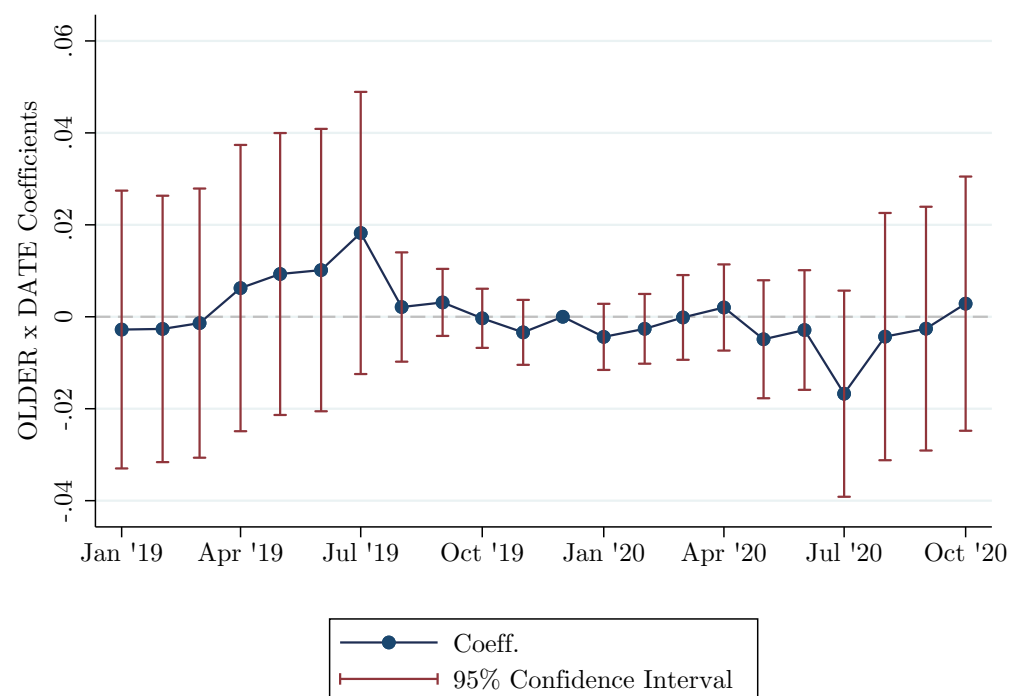

Note: The sample includes 10, 15, and 20-year term policies for individuals aged 20, 25, 30, 35, 60, 65, 70 that appeared at least once from January 2019 to October 2020. Only policies from companies that continuously listed policies on Compulife during the sample period were included. There were 197,268 unique policies from 78 companies for a total of 4,339,896 observations. Controls included policy and month fixed effects and standard errors were clustered at the company level. In panel (a), the dependent variable is an indicator for the policy actively being offered in a given month. In panel (b), the dependent variable is the residuals that result from an estimation of an indicator of policy offering on age-group (i.e., younger and older) fixed effects and age-group by date linear trends on the pre-treatment period (2019). 
Figure 5. Event Study, Influence of COVID on Offerings for Age 75+

(a) 10, 15, and 20-year Term Policies

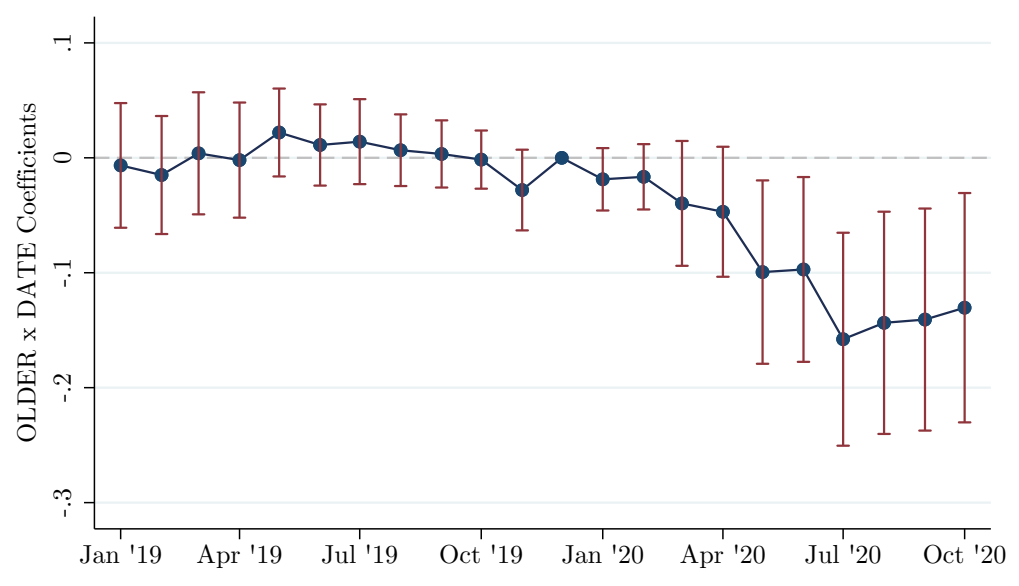

$\longrightarrow$ Coeff.

95\% Confidence Interval

(b) 1, 5, and 10-year Term Policies

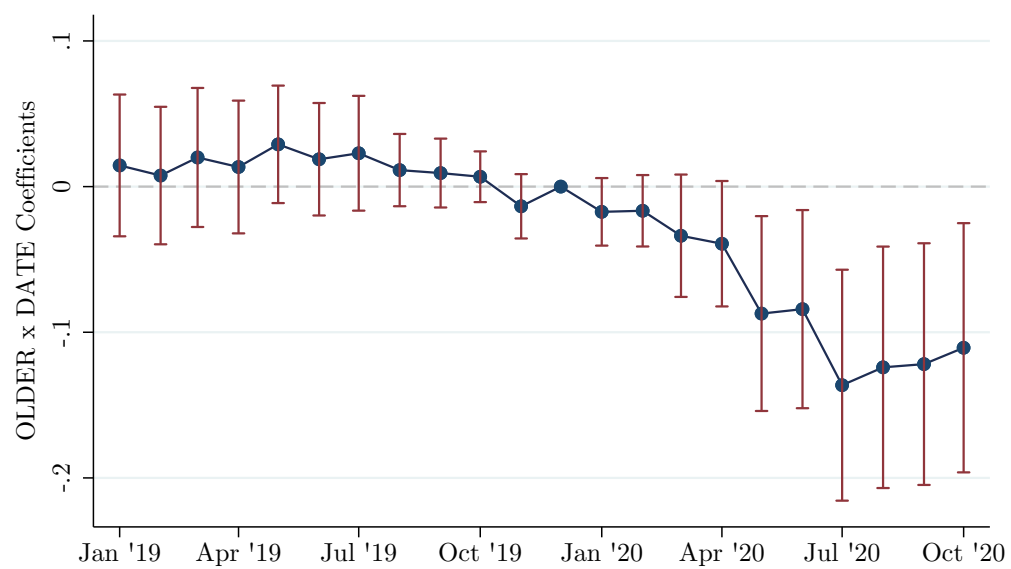

$\longrightarrow$ Coeff.

Note: The sample includes term policies for individuals aged 20, 25, 30, 35, 75, 80, and 85 that appeared at least once from January 2019 to October 2020. Only policies from companies that continuously listed policies on Compulife during the sample period were included. There were 137,405 unique policies from 80 companies for a total of $3,022,910$ observations for the specification presented in panel (a). There were 59,373 unique policies from 78 companies for a total of 1,306,206 observations for the specification presented in panel (b). Controls included policy and month fixed effects and standard errors were clustered at the company level. The dependent variable is an indicator for the policy actively being offered in a given month. 
Table 1-Premium Changes by Company (Index=100 in December 2019)

\begin{tabular}{|c|c|c|c|c|c|c|c|c|c|c|c|}
\hline & Dec & Jan & Feb & Mar & Apr & May & Jun & Jul & Aug & Sep & Oct \\
\hline John Hancock NY & 100.0 & 100.0 & 101.3 & 101.3 & 101.3 & 101.3 & 101.3 & 101.3 & 111.8 & 111.8 & 111.9 \\
\hline Pruco Co of New Jersey & 100.0 & 101.4 & 101.4 & 101.4 & 101.4 & 101.4 & 101.4 & 101.4 & 110.3 & 110.3 & 110.3 \\
\hline Assurity & 100.0 & 100.0 & 100.0 & 100.0 & 107.2 & 107.2 & 107.2 & 107.2 & 107.2 & 107.2 & 107.2 \\
\hline Pacific & 100.0 & 100.3 & 100.3 & 100.3 & 100.3 & 100.3 & 100.3 & 100.3 & 100.3 & 100.3 & 102.9 \\
\hline United States Life NY & 100.0 & 100.0 & 100.0 & 100.0 & 100.0 & 100.0 & 100.0 & 100.0 & 100.0 & 100.0 & 102.8 \\
\hline United of Omaha & 100.0 & 100.5 & 100.5 & 100.5 & 102.8 & 102.8 & 102.8 & 102.8 & 102.8 & 102.8 & 102.8 \\
\hline William Penn Co of NY & 100.0 & 100.0 & 100.0 & 102.0 & 102.0 & 102.5 & 102.5 & 101.9 & 101.9 & 101.9 & 101.9 \\
\hline Columbian & 100.0 & 100.0 & 101.2 & 101.2 & 101.2 & 101.2 & 101.2 & 101.2 & 101.2 & 101.2 & 101.2 \\
\hline AAA & 100.0 & 100.5 & 100.8 & 100.8 & 100.8 & 100.8 & 100.8 & 100.8 & 100.8 & 100.8 & 100.8 \\
\hline John Hancock USA & 100.0 & 100.1 & 100.1 & 100.1 & 100.1 & 100.1 & 100.1 & 100.1 & 100.7 & 100.7 & 100.7 \\
\hline Banner & 100.0 & 100.0 & 100.0 & 100.2 & 100.2 & 100.5 & 100.5 & 101.0 & 101.0 & 100.6 & 100.6 \\
\hline Lincoln National & 100.0 & 100.0 & 100.0 & 99.7 & 99.7 & 100.1 & 100.1 & 100.1 & 100.1 & 100.2 & 100.2 \\
\hline Sagicor & 100.0 & 100.0 & 100.0 & 100.0 & 100.0 & 100.0 & 100.5 & 100.5 & 100.5 & 99.9 & 99.9 \\
\hline Pruco & 100.0 & 100.0 & 100.0 & 100.0 & 100.0 & 100.0 & 100.0 & 100.0 & 99.6 & 99.6 & 99.6 \\
\hline Protective & 100.0 & 100.0 & 99.8 & 99.8 & 99.8 & 99.8 & 99.5 & 99.5 & 99.4 & 99.4 & 99.4 \\
\hline Ameritas Corp of NY & 100.0 & 100.0 & 100.0 & 100.0 & 100.0 & 100.0 & 100.0 & 99.1 & 99.1 & 99.1 & 99.1 \\
\hline American General & 100.0 & 100.0 & 100.3 & 100.3 & 100.3 & 100.3 & 98.9 & 98.9 & 98.9 & 98.9 & 98.9 \\
\hline Massachusetts Mutual & 100.0 & 100.0 & 100.0 & 98.7 & 98.7 & 98.7 & 98.7 & 98.7 & 98.7 & 98.7 & 98.7 \\
\hline Ameritas Corp & 100.0 & 100.0 & 100.0 & 100.0 & 100.0 & 100.0 & 100.0 & 94.9 & 94.9 & 94.9 & 94.9 \\
\hline
\end{tabular}

Note: The sample used to generate the table includes policies that were continuously active from December 2019 to October 2020 with premiums normalized to 100 in December 2019. We report the average of these indexed premiums across companies. We only present the 19 companies that changed their premiums out of 74 companies analyzed. The table is sorted descending based on the October 2020 premium index. 
Table 2-Premium Response to COVID-19: Dependent Variable Log Premiums

\begin{tabular}{|c|c|c|c|c|c|c|c|}
\hline \multirow[t]{2}{*}{ Sample: } & \multirow{2}{*}{$\begin{array}{c}\text { Top } \\
\text { Share }\end{array}$} & \multicolumn{2}{|c|}{ Top Modifier of } & \multicolumn{2}{|c|}{ AM Best Rating } & \multicolumn{2}{|c|}{ Young Healthy \& Older: } \\
\hline & & Premiums & Offerings & A to $\mathrm{A}++$ & $\mathrm{B}+$ to $\mathrm{A}-$ & Rg Health & Rg Health/Smoker \\
\hline \multicolumn{8}{|l|}{ Older $\times$} \\
\hline \multirow[t]{2}{*}{ Jan 2020} & 0.001 & -0.004 & -0.002 & 0.000 & 0.002 & 0.001 & 0.003 \\
\hline & $(0.004)$ & $(0.004)$ & $(0.004)$ & $(0.002)$ & $(0.003)$ & $(0.003)$ & $(0.004)$ \\
\hline \multirow[t]{2}{*}{ Feb 2020} & -0.004 & $-0.009^{*}$ & -0.007 & -0.002 & 0.002 & -0.000 & 0.002 \\
\hline & $(0.005)$ & $(0.005)$ & $(0.005)$ & $(0.002)$ & $(0.003)$ & $(0.003)$ & $(0.004)$ \\
\hline \multirow[t]{2}{*}{ Mar 2020} & -0.004 & $-0.010^{*}$ & -0.007 & -0.002 & 0.002 & -0.002 & 0.001 \\
\hline & $(0.005)$ & $(0.005)$ & $(0.005)$ & $(0.002)$ & $(0.003)$ & $(0.004)$ & $(0.004)$ \\
\hline \multirow[t]{2}{*}{ Apr 2020} & -0.005 & -0.009 & -0.008 & -0.002 & -0.007 & -0.002 & 0.001 \\
\hline & $(0.005)$ & $(0.005)$ & $(0.005)$ & $(0.003)$ & $(0.010)$ & $(0.004)$ & $(0.004)$ \\
\hline \multirow[t]{2}{*}{ May 2020} & -0.005 & -0.008 & -0.008 & -0.002 & -0.007 & -0.002 & 0.001 \\
\hline & $(0.005)$ & $(0.005)$ & $(0.005)$ & $(0.003)$ & $(0.010)$ & $(0.004)$ & $(0.004)$ \\
\hline \multirow[t]{2}{*}{ Jun 2020} & -0.005 & -0.008 & -0.007 & -0.001 & -0.007 & -0.001 & 0.002 \\
\hline & $(0.006)$ & $(0.006)$ & $(0.005)$ & $(0.003)$ & $(0.010)$ & $(0.004)$ & $(0.005)$ \\
\hline \multirow[t]{2}{*}{ Jul 2020} & -0.005 & -0.008 & -0.007 & -0.001 & -0.007 & -0.001 & 0.003 \\
\hline & $(0.006)$ & $(0.006)$ & $(0.006)$ & $(0.003)$ & $(0.010)$ & $(0.004)$ & $(0.005)$ \\
\hline \multirow[t]{2}{*}{ Aug 2020} & -0.001 & -0.007 & -0.007 & -0.001 & -0.007 & 0.004 & 0.007 \\
\hline & $(0.007)$ & $(0.007)$ & $(0.007)$ & $(0.003)$ & $(0.010)$ & $(0.004)$ & $(0.005)$ \\
\hline \multirow[t]{2}{*}{ Sep 2020} & -0.001 & -0.007 & -0.006 & -0.001 & -0.007 & 0.004 & $0.008^{*}$ \\
\hline & $(0.007)$ & $(0.007)$ & $(0.006)$ & $(0.003)$ & $(0.010)$ & $(0.004)$ & $(0.005)$ \\
\hline \multirow[t]{2}{*}{ Oct 2020} & -0.001 & -0.007 & -0.006 & -0.001 & -0.007 & 0.005 & $0.009^{*}$ \\
\hline & $(0.007)$ & $(0.007)$ & $(0.006)$ & $(0.003)$ & $(0.011)$ & $(0.004)$ & $(0.005)$ \\
\hline Observations & $1,080,208$ & 770,701 & 962,543 & $2,208,112$ & 364,600 & 942,024 & 724,357 \\
\hline Policies & 96,205 & 56,166 & 90,427 & 171,798 & 20,540 & 72,551 & 56,437 \\
\hline Companies & 29 & 18 & 25 & 62 & 17 & 93 & 93 \\
\hline
\end{tabular}

Note: The unbalanced panel includes 10, 15, and 20-year term policies listed on Compulife from January 2019 to October 2020 that were offered to individuals aged 20, 25, 30, 35, 60, 65, and 70. Top Share refers to companies listed in the top 25 for market share (or whose parent company is listed) by National Association of Insurance Commissioners. The top modifier of premiums and offerings indicate companies in the top quartile of activity respectively based on changes from 2014 to 2018. AM Best Ratings are indicators of a companies ability to meet financial obligations. The second to last column includes policies s to younger individuals (age 20 to 35) who do not smoke in the best health categories and older individuals in the worst health category. The last column further restrict the policies s to older individuals to those that smoke. Policy and month fixed effects were included but not reported here. Standard errors are clustered at the company level and are shown in parentheses ${ }^{* * *} \mathrm{p}<0.01,{ }^{* *} \mathrm{p}<0.05,{ }^{*} \mathrm{p}<0.1$. 
Table 3-Log Premium Response by Term Length \& Face Value

\begin{tabular}{|c|c|c|c|c|c|c|c|c|c|c|}
\hline & \multicolumn{3}{|c|}{ Term Length } & \multicolumn{7}{|c|}{ Face Value } \\
\hline & 10-year & 15 -year & 20-year & $\$ 100 \mathrm{k}$ & $\$ 250 \mathrm{k}$ & $\$ 500 \mathrm{k}$ & $\$ 750 \mathrm{k}$ & $\$ 1 \mathrm{~m}$ & $\$ 5 \mathrm{~m}$ & $\$ 10 \mathrm{~m}$ \\
\hline \multicolumn{11}{|l|}{ Older $\times$} \\
\hline Jan 2020 & $\begin{array}{c}0.000 \\
(0.002)\end{array}$ & $\begin{array}{c}0.000 \\
(0.002)\end{array}$ & $\begin{array}{r}-0.000 \\
(0.002)\end{array}$ & $\begin{array}{c}0.001 \\
(0.002)\end{array}$ & $\begin{array}{c}0.000 \\
(0.002)\end{array}$ & $\begin{array}{r}-0.000 \\
(0.002)\end{array}$ & $\begin{array}{r}-0.000 \\
(0.002)\end{array}$ & $\begin{array}{r}-0.000 \\
(0.002)\end{array}$ & $\begin{array}{c}0.000 \\
(0.002)\end{array}$ & $\begin{array}{c}0.001 \\
(0.002)\end{array}$ \\
\hline Feb 2020 & $\begin{array}{r}-0.002 \\
(0.002)\end{array}$ & $\begin{array}{c}-0.001 \\
(0.002)\end{array}$ & $\begin{array}{c}-0.001 \\
(0.002)\end{array}$ & $\begin{array}{r}-0.000 \\
(0.002)\end{array}$ & $\begin{array}{c}-0.001 \\
(0.002)\end{array}$ & $\begin{array}{r}-0.002 \\
(0.002)\end{array}$ & $\begin{array}{r}-0.002 \\
(0.002)\end{array}$ & $\begin{array}{r}-0.002 \\
(0.002)\end{array}$ & $\begin{array}{c}-0.001 \\
(0.002)\end{array}$ & $\begin{array}{r}-0.001 \\
(0.002)\end{array}$ \\
\hline Mar 2020 & $\begin{array}{r}-0.002 \\
(0.002)\end{array}$ & $\begin{array}{r}-0.001 \\
(0.002)\end{array}$ & $\begin{array}{r}-0.001 \\
(0.002)\end{array}$ & $\begin{array}{c}-0.003 \\
(0.004)\end{array}$ & $\begin{array}{r}-0.001 \\
(0.002)\end{array}$ & $\begin{array}{r}-0.002 \\
(0.002)\end{array}$ & $\begin{array}{r}-0.002 \\
(0.002)\end{array}$ & $\begin{array}{r}-0.002 \\
(0.002)\end{array}$ & $\begin{array}{r}-0.001 \\
(0.002)\end{array}$ & $\begin{array}{r}-0.001 \\
(0.002)\end{array}$ \\
\hline Apr 2020 & $\begin{array}{c}-0.003 \\
(0.003)\end{array}$ & $\begin{array}{c}-0.002 \\
(0.003)\end{array}$ & $\begin{array}{c}-0.002 \\
(0.003)\end{array}$ & $\begin{array}{c}-0.004 \\
(0.004)\end{array}$ & $\begin{array}{c}-0.003 \\
(0.003)\end{array}$ & $\begin{array}{c}-0.003 \\
(0.002)\end{array}$ & $\begin{array}{c}-0.003 \\
(0.003)\end{array}$ & $\begin{array}{c}-0.003 \\
(0.003)\end{array}$ & $\begin{array}{c}-0.002 \\
(0.003)\end{array}$ & $\begin{array}{c}-0.002 \\
(0.003)\end{array}$ \\
\hline May 2020 & $\begin{array}{c}-0.003 \\
(0.003)\end{array}$ & $\begin{array}{c}-0.002 \\
(0.003)\end{array}$ & $\begin{array}{c}-0.003 \\
(0.003)\end{array}$ & $\begin{array}{c}-0.004 \\
(0.004)\end{array}$ & $\begin{array}{c}-0.002 \\
(0.003)\end{array}$ & $\begin{array}{c}-0.002 \\
(0.002)\end{array}$ & $\begin{array}{c}-0.003 \\
(0.003)\end{array}$ & $\begin{array}{r}-0.003 \\
(0.003)\end{array}$ & $\begin{array}{r}-0.002 \\
(0.003)\end{array}$ & $\begin{array}{r}-0.002 \\
(0.003)\end{array}$ \\
\hline Jun 2020 & $\begin{array}{c}-0.002 \\
(0.003)\end{array}$ & $\begin{array}{r}-0.002 \\
(0.003)\end{array}$ & $\begin{array}{c}-0.002 \\
(0.003)\end{array}$ & $\begin{array}{r}-0.004 \\
(0.004)\end{array}$ & $\begin{array}{r}-0.002 \\
(0.003)\end{array}$ & $\begin{array}{r}-0.002 \\
(0.002)\end{array}$ & $\begin{array}{c}-0.003 \\
(0.003)\end{array}$ & $\begin{array}{c}-0.002 \\
(0.003)\end{array}$ & $\begin{array}{c}-0.002 \\
(0.003)\end{array}$ & $\begin{array}{r}-0.002 \\
(0.003)\end{array}$ \\
\hline Jul 2020 & $\begin{array}{r}-0.003 \\
(0.003)\end{array}$ & $\begin{array}{r}-0.002 \\
(0.003)\end{array}$ & $\begin{array}{r}-0.002 \\
(0.003)\end{array}$ & $\begin{array}{r}-0.004 \\
(0.004)\end{array}$ & $\begin{array}{r}-0.002 \\
(0.003)\end{array}$ & $\begin{array}{r}-0.002 \\
(0.003)\end{array}$ & $\begin{array}{r}-0.002 \\
(0.003)\end{array}$ & $\begin{array}{r}-0.002 \\
(0.003)\end{array}$ & $\begin{array}{r}-0.002 \\
(0.003)\end{array}$ & $\begin{array}{r}-0.001 \\
(0.003)\end{array}$ \\
\hline Aug 2020 & $\begin{array}{r}-0.003 \\
(0.003)\end{array}$ & $\begin{array}{r}-0.002 \\
(0.004)\end{array}$ & $\begin{array}{r}-0.002 \\
(0.003)\end{array}$ & $\begin{array}{r}-0.004 \\
(0.004)\end{array}$ & $\begin{array}{r}-0.003 \\
(0.003)\end{array}$ & $\begin{array}{r}-0.002 \\
(0.003)\end{array}$ & $\begin{array}{r}-0.003 \\
(0.003)\end{array}$ & $\begin{array}{r}-0.002 \\
(0.003)\end{array}$ & $\begin{array}{r}-0.001 \\
(0.003)\end{array}$ & $\begin{array}{r}-0.001 \\
(0.003)\end{array}$ \\
\hline Sep 2020 & $\begin{array}{c}-0.003 \\
(0.003)\end{array}$ & $\begin{array}{c}-0.002 \\
(0.004)\end{array}$ & $\begin{array}{r}-0.001 \\
(0.003)\end{array}$ & $\begin{array}{r}-0.004 \\
(0.004)\end{array}$ & $\begin{array}{c}-0.003 \\
(0.003)\end{array}$ & $\begin{array}{c}-0.002 \\
(0.003)\end{array}$ & $\begin{array}{c}-0.002 \\
(0.003)\end{array}$ & $\begin{array}{r}-0.002 \\
(0.003)\end{array}$ & $\begin{array}{c}-0.001 \\
(0.003)\end{array}$ & $\begin{array}{r}-0.001 \\
(0.003)\end{array}$ \\
\hline Oct 2020 & $\begin{array}{c}-0.003 \\
(0.003)\end{array}$ & $\begin{array}{r}-0.002 \\
(0.004)\end{array}$ & $\begin{array}{c}-0.001 \\
(0.003)\end{array}$ & $\begin{array}{c}-0.003 \\
(0.004)\end{array}$ & $\begin{array}{c}-0.003 \\
(0.003)\end{array}$ & $\begin{array}{r}-0.002 \\
(0.003)\end{array}$ & $\begin{array}{c}-0.002 \\
(0.003)\end{array}$ & $\begin{array}{c}-0.001 \\
(0.003)\end{array}$ & $\begin{array}{r}-0.001 \\
(0.003)\end{array}$ & $\begin{array}{r}-0.001 \\
(0.003)\end{array}$ \\
\hline Observations & 958,500 & 929,729 & 844,899 & 333,672 & 390,679 & 398,430 & 396,728 & 411,938 & 401,318 & 400,363 \\
\hline Policies & 73,067 & 70,664 & 63,851 & 22,280 & 30,042 & 30,740 & 30,556 & 31,761 & 31,127 & 31,076 \\
\hline Companies & 90 & 82 & 90 & 80 & 89 & 86 & 83 & 87 & 82 & 80 \\
\hline
\end{tabular}

Note: The unbalanced panel includes 10, 15, and 20-year term policies listed on Compulife from January 2019 to October 2020 that were offered to individuals aged 20, 25, 30, 35, 60, 65, and 70. Policy and month fixed effects were included but not reported here. Standard errors are clustered at the company level and are shown in parentheses ${ }^{* * *} \mathrm{p}<0.01,{ }^{* *} \mathrm{p}<0.05$, 
Table 4-Price Competition: Dependent Variable Log Premiums

\begin{tabular}{|c|c|c|c|}
\hline & Not Lowest Price & Lowest price & Lowest Price $\geq 1 \%$ Gap \\
\hline \multicolumn{4}{|l|}{ Older $x$} \\
\hline \multirow[t]{2}{*}{ Jan 2020} & -0.000 & 0.000 & 0.004 \\
\hline & $(0.003)$ & $(0.001)$ & $(0.004)$ \\
\hline \multirow[t]{2}{*}{ Feb 2020} & -0.003 & 0.000 & 0.004 \\
\hline & $(0.003)$ & $(0.001)$ & $(0.004)$ \\
\hline \multirow[t]{2}{*}{ Mar 2020} & -0.005 & $0.002^{*}$ & 0.006 \\
\hline & $(0.004)$ & $(0.001)$ & $(0.004)$ \\
\hline \multirow[t]{2}{*}{ Apr 2020} & -0.005 & $0.002^{*}$ & 0.006 \\
\hline & $(0.004)$ & $(0.001)$ & $(0.004)$ \\
\hline \multirow[t]{2}{*}{ May 2020} & -0.005 & $0.003^{*}$ & 0.007 \\
\hline & $(0.004)$ & $(0.002)$ & $(0.004)$ \\
\hline \multirow[t]{2}{*}{ Jun 2020} & -0.005 & $0.004^{* *}$ & $0.007^{*}$ \\
\hline & $(0.004)$ & $(0.002)$ & $(0.004)$ \\
\hline \multirow[t]{2}{*}{ Jul 2020} & -0.005 & $0.007^{*}$ & $0.013^{* *}$ \\
\hline & $(0.004)$ & $(0.004)$ & $(0.006)$ \\
\hline \multirow[t]{2}{*}{ Aug 2020} & -0.003 & $0.008^{* *}$ & $0.013^{* *}$ \\
\hline & $(0.005)$ & $(0.004)$ & $(0.006)$ \\
\hline \multirow[t]{2}{*}{ Sep 2020} & -0.003 & $0.008^{* *}$ & $0.013^{* *}$ \\
\hline & $(0.005)$ & $(0.004)$ & $(0.005)$ \\
\hline \multirow[t]{2}{*}{ Oct 2020} & -0.002 & $0.008^{* *}$ & $0.013^{* *}$ \\
\hline & $(0.005)$ & $(0.004)$ & $(0.005)$ \\
\hline Observations & $1,044,891$ & 28,761 & 9,383 \\
\hline Policies & 64,527 & 1,513 & 486 \\
\hline Companies & 35 & 30 & 17 \\
\hline
\end{tabular}

Note: The unbalanced panel includes 10, 15, and 20-year term policies listed on Compulife from January 2019 to October 2020 that were offered to individuals aged 20, 25, 30, 35, 60, 65, and 70. The sample is restricted to companies with $\mathrm{A}++$ or A+ AM Best Ratings. Premium comparisons in December 2019 were used to determine if the policy was the low price leader or not. Policy and month fixed effects were included but not reported here. Standard errors are clustered at the company level and are shown in parentheses ${ }^{* * *} \mathrm{p}<0.01,{ }^{* *} \mathrm{p}<0.05,{ }^{*} \mathrm{p}<0.1$. 
Table 5-Subsample Analysis: The Influence of COVID-19 on Policy Offerings

\begin{tabular}{|c|c|c|c|c|c|c|c|}
\hline \multirow[t]{2}{*}{ Sample: } & \multirow{2}{*}{$\begin{array}{l}\text { Top } \\
\text { Share }\end{array}$} & \multicolumn{2}{|c|}{ Top Modifier of } & \multicolumn{2}{|c|}{ AM Best Rating } & \multicolumn{2}{|c|}{ Young Healthy \& Older: } \\
\hline & & Premiums & Offerings & A to $\mathrm{A}++$ & $\mathrm{B}+$ to $\mathrm{A}-$ & Rg Health & Rg Health/Smoker \\
\hline \multicolumn{8}{|l|}{ Older $\times$} \\
\hline Jan 2020 & $\begin{array}{r}-0.010 \\
(0.017)\end{array}$ & $\begin{array}{c}0.003 \\
(0.010)\end{array}$ & $\begin{array}{r}-0.006 \\
(0.020)\end{array}$ & $\begin{array}{r}-0.007 \\
(0.011)\end{array}$ & $\begin{array}{c}-0.008 \\
(0.011)\end{array}$ & $\begin{array}{r}-0.012 \\
(0.013)\end{array}$ & $\begin{array}{r}-0.013 \\
(0.013)\end{array}$ \\
\hline Feb 2020 & $\begin{array}{c}-0.004 \\
(0.018)\end{array}$ & $\begin{array}{c}0.005 \\
(0.009)\end{array}$ & $\begin{array}{c}-0.000 \\
(0.020)\end{array}$ & $\begin{array}{c}-0.004 \\
(0.011)\end{array}$ & $\begin{array}{c}-0.012 \\
(0.012)\end{array}$ & $\begin{array}{r}-0.010 \\
(0.014)\end{array}$ & $\begin{array}{r}-0.011 \\
(0.013)\end{array}$ \\
\hline Mar 2020 & $\begin{array}{c}0.005 \\
(0.018)\end{array}$ & $\begin{array}{c}0.005 \\
(0.009)\end{array}$ & $\begin{array}{c}0.008 \\
(0.020)\end{array}$ & $\begin{array}{r}-0.001 \\
(0.011)\end{array}$ & $\begin{array}{r}-0.012 \\
(0.013)\end{array}$ & $\begin{array}{r}-0.005 \\
(0.014)\end{array}$ & $\begin{array}{r}-0.005 \\
(0.014)\end{array}$ \\
\hline Apr 2020 & $\begin{array}{c}0.011 \\
(0.018)\end{array}$ & $\begin{array}{c}0.000 \\
(0.006)\end{array}$ & $\begin{array}{c}0.015 \\
(0.020)\end{array}$ & $\begin{array}{c}0.001 \\
(0.011)\end{array}$ & $\begin{array}{c}-0.011 \\
(0.013)\end{array}$ & $\begin{array}{r}-0.002 \\
(0.014)\end{array}$ & $\begin{array}{c}-0.002 \\
(0.013)\end{array}$ \\
\hline May 2020 & $\begin{array}{c}-0.005 \\
(0.020)\end{array}$ & $\begin{array}{c}-0.011 \\
(0.014)\end{array}$ & $\begin{array}{c}0.010 \\
(0.020)\end{array}$ & $\begin{array}{r}-0.007 \\
(0.012)\end{array}$ & $\begin{array}{c}-0.008 \\
(0.012)\end{array}$ & $\begin{array}{r}-0.008 \\
(0.014)\end{array}$ & $\begin{array}{r}-0.007 \\
(0.014)\end{array}$ \\
\hline Jun 2020 & $\begin{array}{c}-0.001 \\
(0.020)\end{array}$ & $\begin{array}{c}-0.010 \\
(0.014)\end{array}$ & $\begin{array}{c}0.016 \\
(0.021)\end{array}$ & $\begin{array}{c}-0.005 \\
(0.012)\end{array}$ & $\begin{array}{r}-0.007 \\
(0.012)\end{array}$ & $\begin{array}{r}-0.016 \\
(0.018)\end{array}$ & $\begin{array}{c}-0.014 \\
(0.018)\end{array}$ \\
\hline Jul 2020 & $\begin{array}{r}-0.007 \\
(0.019)\end{array}$ & $\begin{array}{r}-0.051^{*} \\
(0.027)\end{array}$ & $\begin{array}{c}0.018 \\
(0.019)\end{array}$ & $\begin{array}{r}-0.019 \\
(0.014)\end{array}$ & $\begin{array}{r}-0.024 \\
(0.016)\end{array}$ & $\begin{array}{r}-0.029 \\
(0.021)\end{array}$ & $\begin{array}{r}-0.028 \\
(0.020)\end{array}$ \\
\hline Aug 2020 & $\begin{array}{c}0.015 \\
(0.025)\end{array}$ & $\begin{array}{c}-0.032 \\
(0.036)\end{array}$ & $\begin{array}{c}0.040^{*} \\
(0.023)\end{array}$ & $\begin{array}{c}-0.004 \\
(0.016)\end{array}$ & $\begin{array}{c}-0.025 \\
(0.016)\end{array}$ & $\begin{array}{r}-0.010 \\
(0.026)\end{array}$ & $\begin{array}{c}-0.009 \\
(0.025)\end{array}$ \\
\hline Sep 2020 & $\begin{array}{c}0.018 \\
(0.025)\end{array}$ & $\begin{array}{r}-0.032 \\
(0.036)\end{array}$ & $\begin{array}{c}0.045^{*} \\
(0.023)\end{array}$ & $\begin{array}{c}-0.003 \\
(0.016)\end{array}$ & $\begin{array}{r}-0.021 \\
(0.016)\end{array}$ & $\begin{array}{r}-0.006 \\
(0.026)\end{array}$ & $\begin{array}{r}-0.005 \\
(0.025)\end{array}$ \\
\hline Oct 2020 & $\begin{array}{c}0.029 \\
(0.026)\end{array}$ & $\begin{array}{r}-0.032 \\
(0.036)\end{array}$ & $\begin{array}{l}0.056^{* *} \\
(0.024)\end{array}$ & $\begin{array}{c}0.003 \\
(0.017)\end{array}$ & $\begin{array}{r}-0.020 \\
(0.016)\end{array}$ & $\begin{array}{c}0.001 \\
(0.026)\end{array}$ & $\begin{array}{c}0.002 \\
(0.025)\end{array}$ \\
\hline Observations & $2,114,002$ & $1,163,668$ & $2,111,296$ & $3,805,912$ & 427,152 & $1,510,960$ & $1,178,958$ \\
\hline Policies & 96,091 & 52,894 & 95,968 & 172,996 & 19,416 & 68,680 & 53,589 \\
\hline Companies & 25 & 15 & 23 & 57 & 15 & 78 & 78 \\
\hline Percent Active & 0.49 & 0.61 & 0.46 & 0.56 & 0.81 & 0.58 & 0.57 \\
\hline
\end{tabular}

Note: As the dependent variable, the specifications use the residuals that result from an estimation of an indicator of policy offering on age-group (i.e., younger and older) fixed effects and age-group by date linear trends on the pre-treatment period. The sample includes 10,15, and 20-year term policies for individuals aged $20,25,30,35,60,65,70$ that appeared at least once from January 2019 to October 2020. Only policies from companies that continuously listed policies on Compulife during the sample period were included. Policy and month fixed effects were included but not reported here. Standard errors are clustered at the company level and are shown in parentheses ${ }^{* * *} \mathrm{p}<0.01,{ }^{* *} \mathrm{p}<0.05,{ }^{*} \mathrm{p}<0.1$. 
Table 6-Policy Offering Analysis by Term \& Face Value

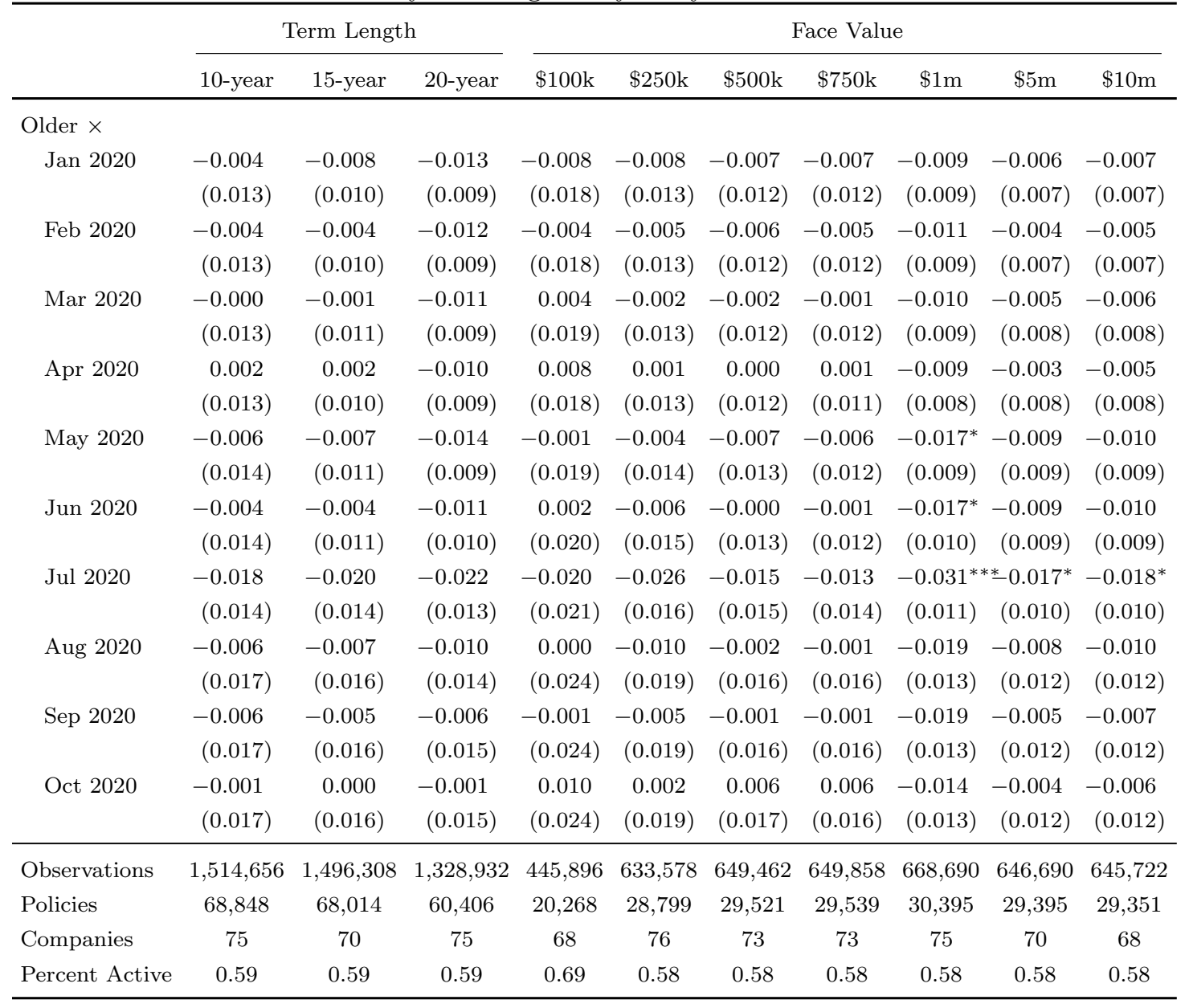

Note: As the dependent variable, the specifications use the residuals that result from an estimation of an indicator of policy offering on age-group (i.e., younger and older) fixed effects and age-group by date linear trends on the pre-treatment period. The sample includes 10, 15, and 20-year term policies for individuals aged 20, 25, 30, 35, 60, 65, 70 that appeared at least once from January 2019 to October 2020. Only policies from companies that continuously listed policies on Compulife during the sample period were included. Policy and month fixed effects were included but not reported here. Standard errors are clustered at the company level and are shown in parentheses ${ }^{* *} \mathrm{p}<0.01,{ }^{* *} \mathrm{p}<0.05,{ }^{*} \mathrm{p}<0.1$. 
Table 7-Influence of COVID-19 on New York Policies

\begin{tabular}{lcccc}
\hline Dependent Variable: & \multicolumn{2}{c}{ Log Premiums } & \multicolumn{2}{c}{ Policy Offered } \\
\hline Older $\times$ & & & & \\
Jan 2019 & -0.001 & $(0.004)$ & -0.005 & $(0.011)$ \\
Feb 2019 & -0.001 & $(0.004)$ & -0.005 & $(0.011)$ \\
March 2019 & -0.001 & $(0.004)$ & 0.002 & $(0.007)$ \\
April 2019 & -0.001 & $(0.004)$ & 0.003 & $(0.007)$ \\
May 2019 & -0.001 & $(0.004)$ & $0.008^{*}$ & $(0.004)$ \\
June 2019 & -0.002 & $(0.004)$ & $0.008^{*}$ & $(0.004)$ \\
July 2019 & -0.002 & $(0.004)$ & $0.008^{*}$ & $(0.004)$ \\
Aug 2019 & -0.003 & $(0.004)$ & 0.004 & $(0.003)$ \\
Sep 2019 & 0.001 & $(0.001)$ & 0.004 & $(0.003)$ \\
Oct 2019 & 0.001 & $(0.001)$ & 0.004 & $(0.003)$ \\
Nov 2019 & 0.000 & $(0.000)$ & 0.004 & $(0.003)$ \\
Jan 2020 & 0.000 & $(0.000)$ & -0.007 & $(0.009)$ \\
Feb 2020 & -0.006 & $(0.006)$ & -0.008 & $(0.009)$ \\
Mar 2020 & -0.008 & $(0.006)$ & -0.008 & $(0.009)$ \\
Apr 2020 & -0.009 & $(0.006)$ & -0.008 & $(0.009)$ \\
May 2020 & -0.008 & $(0.006)$ & -0.020 & $(0.015)$ \\
Jun 2020 & -0.008 & $(0.006)$ & -0.020 & $(0.015)$ \\
Jul 2020 & -0.009 & $(0.007)$ & -0.036 & $(0.022)$ \\
Aug 2020 & -0.009 & $(0.008)$ & -0.036 & $(0.022)$ \\
Sep 2020 & -0.008 & $(0.008)$ & -0.036 & $(0.022)$ \\
Oct 2020 & -0.008 & $(0.008)$ & -0.036 & $(0.022)$ \\
\hline Observations & 753,987 & & $1,142,988$ & \\
Policies & 61,265 & & 51,954 & \\
Companies & 31 & & 23 & \\
\hline
\end{tabular}

Note: The sample is restricted to policies that were offered in New York but not in New Mexico. The panel includes 10, 15, and 20-year term policies listed on Compulife from January 2019 to October 2020 that were offered to individuals aged 20, 25, 30, $35,60,65$, and 70. Only policies from companies that continuously listed policies on Compulife during the sample period were included in the policy offered specification. Standard errors are clustered at the company level and are shown in parentheses ${ }^{* * *}$ $\mathrm{p}<0.01,{ }^{* *} \mathrm{p}<0.05,{ }^{*} \mathrm{p}<0.1$. 


\section{Appendix A: Data Appendix (For Online Publichtion)}

We clean the Compulife data using straightforward practices to increase the quality of the sample. Change logs provided with the Compulife software detail instances where the policies quoted for a given month are misreported due to incorrect or missing information. The logs typically indicate that these errors are noted and corrected quickly. The software is updated at least monthly with policy changes, but in some instances mid-month updates are issued to correct minor errors. Nonetheless, the historical data do not seem to be corrected as the software is designed for for use by life insurance agents quoting current policies options. The following steps were taken to correct for these errors and other irregularities in the data.

These data start with 902,968 unique policies. In the case of duplicate conflicting entries for a single policy in a given month, we use the premium based on the following criteria: First, if one of the premium amounts matches both the previous and post month premiums then we use that premium. If not, we use the premium that matches the following month's premium. If the next month's premium is one of the duplicate entries, we use the previous the observation that matches the month's premium. If the duplicate premium options do not match either the previous or subsequent premiums then we omit the policy (not just the observation) from the sample. These omission consist of 3,331 policies ( 0.4 percent).

To remove outliers, we omit policies that have abnormally large month to month changes in premiums. We exclude observations that had more than a 25 percent increase or decrease in annual premiums in relation to the previous month's premium (roughly corresponding to the 1st and 99th percentile of premium changes). We drop 0.2 percent of the remaining sample with this restriction (1,974 policies). Figure A1 presents the distribution of premium changes after the minor restriction.

Of the term policies in the sample, 88.8 percent turn on and then off at most once ("continuous"), with the remainder turning on and off more than once. Some policies were not reported for one to two months, likely reflecting a lack of information provision rather than a discontinuation of the policy and then a new offering of the policy. For these circumstances, we impute the missing values using the premiums before and after the missing data. If the premiums before and after are the same, we merely continue the policy with the same premium. If the premiums change before and after the missing observation, we use the premium from the month preceding the missing observation. With the imputations, the proportion of policies that are continuous increases to 93.0 percent. 
Given that our main sample period is 2019 and 2020, we remove the 20 companies that did not list policies at all during 2019 and 2020. Out of the remaining 100 companies, we drop those in the bottom five percent in terms of policies offered from 2019 to 2020. These restrictions along with limiting the main sample to policies for individuals age 20 to 70 result in a sample with 804,242 policies and 95 companies.

Figure A1. Premium Changes Histogram

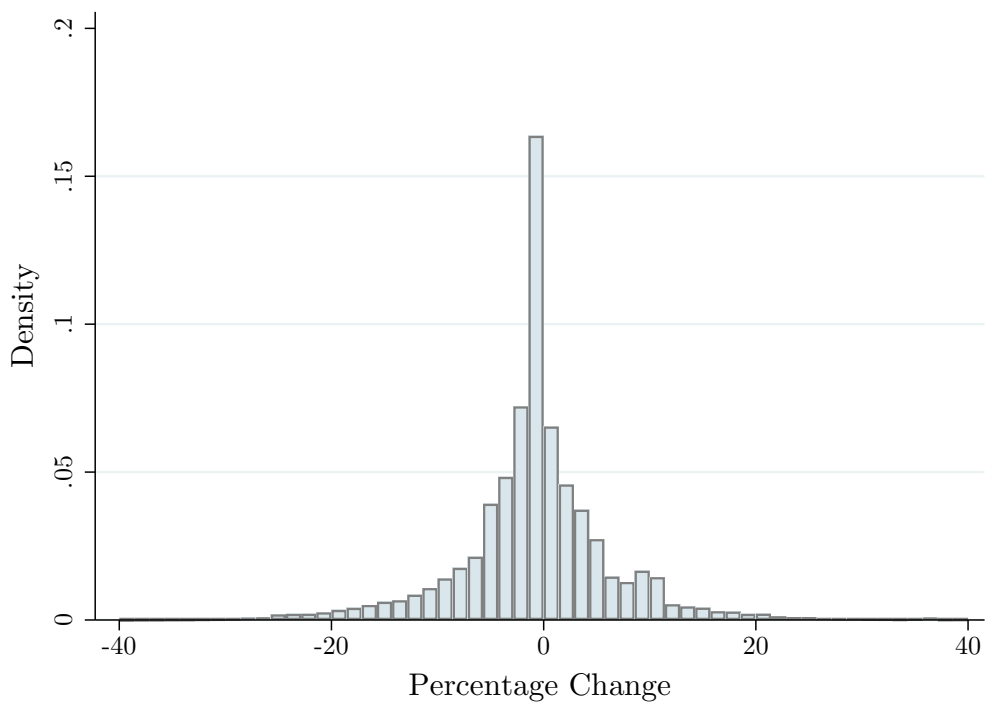


Figure A2. Distribution of Policies Offerings and Companies by Age

(a) Policies Distribution

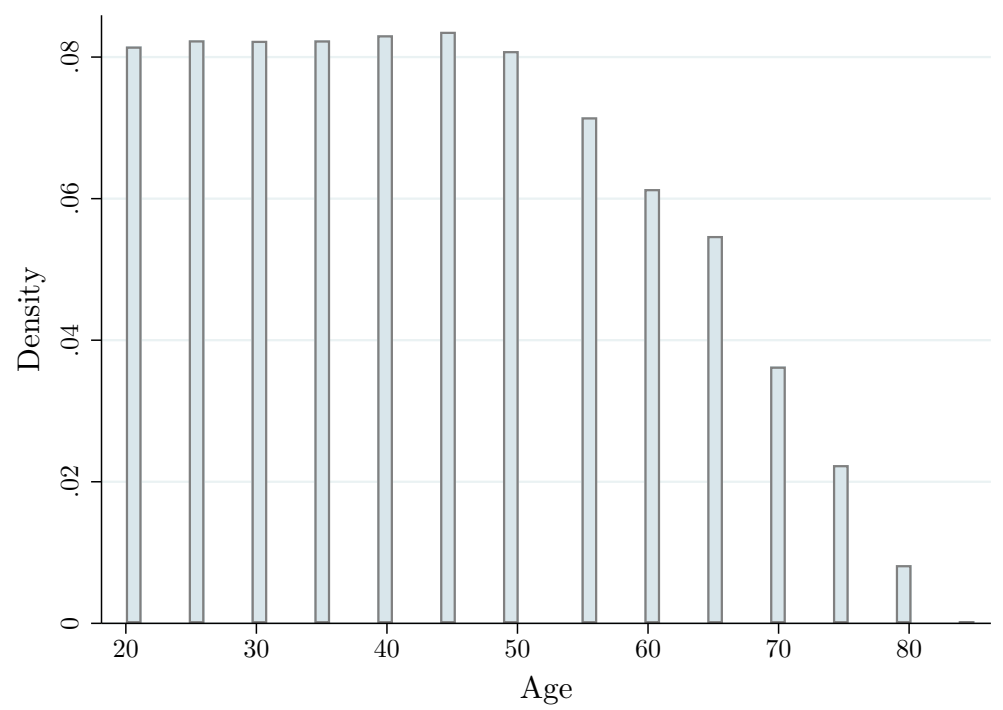

(b) Company Frequency

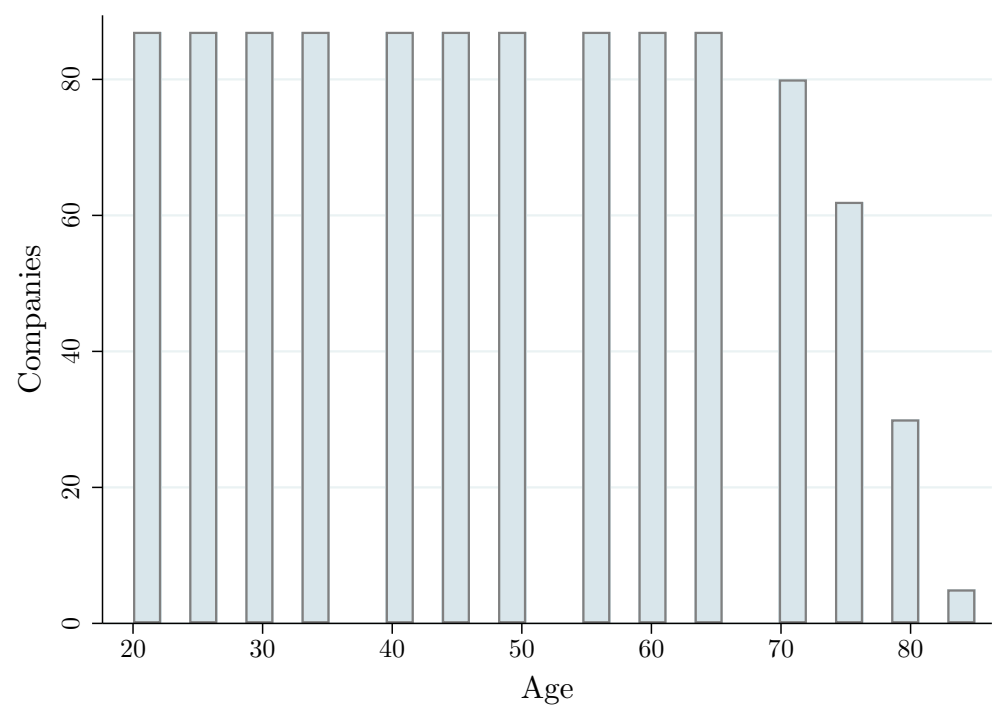

Note: The sample includes term policies and companies using Compulife data from December 2019. 